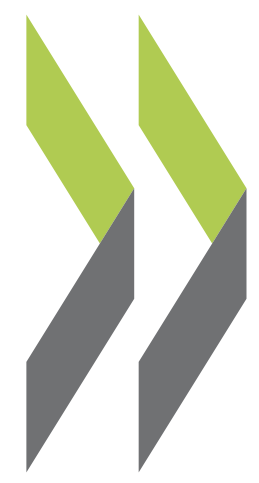

OECD Economics Department Working Papers No. 1364

Enhancing skills to boost growth in Hungary

\author{
Gabriel Machlica
}


Organisation de Coopération et de Développement Économiques

Organisation for Economic Co-operation and Development

21-Dec-2016

ECONOMICS DEPARTMENT

English - Or. English

\section{ENHANCING SKILLS TO BOOST GROWTH IN HUNGARY}

ECONOMICS DEPARTMENT WORKING PAPERS No. 1364

\section{By Gabriel Machlica}

OECD Working Papers should not be reported as representing the official views of the OECD or of its member countries. The opinions expressed and arguments employed are those of the author(s).

Authorised for publication by Robert Ford, Deputy Director, Country Studies Branch, Economics Department.

All Economics Department Working Papers are available at www.oecd.org/eco/workingpapers

JT03407371

Complete document available on OLIS in its original format

This document and any map included herein are without prejudice to the status of or sovereignty over any territory, to the delimitation of international frontiers and boundaries and to the name of any territory, city or area. 
OECD Working Papers should not be reported as representing the official views of the OECD or of its member countries. The opinions expressed and arguments employed are those of the author(s).

Working Papers describe preliminary results or research in progress by the author(s) and are published to stimulate discussion on a broad range of issues on which the OECD works.

Comments on Working Papers are welcomed, and may be sent to OECD Economics Department, 2 Rue André Pascal, 75775 Paris Cedex 16, France, or by e-mail to eco.contact@oecd.org.

All Economics Department Working Papers are available at www.oecd.org/eco/workingpapers.

This document and any map included herein are without prejudice to the status of or sovereignty over any territory, to the delimitation of international frontiers and boundaries and to the name of any territory, city or area.

The statistical data for Israel are supplied by and under the responsibility of the relevant Israeli authorities. The use of such data by the OECD is without prejudice to the status of the Golan Heights, East Jerusalem and Israeli settlements in the West Bank under the terms of international law.

Latvia was not an OECD Member at the time of preparation of this publication. Accordingly, Latvia does not appear in the list of OECD Members and is not included in the zone aggregates.

\section{(C) OECD (2016)}

You can copy, download or print OECD content for your own use, and you can include excerpts from OECD publications, databases and multimedia products in your own documents, presentations, blogs, websites and teaching materials, provided that suitable acknowledgment of OECD as source and copyright owner is given. All requests for commercial use and translation rights should be submitted to rights@oecd.org 


\section{ABSTRACT/RÉSUMÉ}

\section{Enhancing skills to boost growth in Hungary}

Skill requirements in the labour market have significantly changed over the past two decades. The restructuring of the economy is making the labour market increasingly knowledge-based. The education system has reacted to this structural change, but as the pace has been relatively slow, many graduates remain without adequate skills and insufficiently prepared to apply knowledge in unfamiliar settings. Moreover, strong selectivity early in the education system reinforces student's socio-economic background, leading to an excess of low skilled workers with poor labour market prospects. This contributes to persistently low employment rates and low productivity gains, slowing down the income convergence process. The education system needs to improve learning outcomes by better aligning student qualifications with labour market needs. Improving overall educational outcomes would also make the education system more equitable and inclusive. Bolstering the supply of skills requires lifelong learning and improving the access to labour market to those who have left the education system without proper skills. In return, this will also increase "on-the-job" training, which is a key driver of acquiring competences after graduation. In addition, mobilising untapped skill resources, particular educated younger women, would raise employment, which is needed to confront the labour market problem arising from population ageing.

This working paper relates to the 2016 OECD Economic Survey of Hungary (www.oecd.org/eco/surveys/economic-survey-hungary.htm).

JEL Classification: I23; I25; I28; J48

Keywords: Skills, vocational education, training, labour market, active labour market policies.

***********************************

\section{Améliorer les compétences pour dynamiser la croissance en Hongrie}

Les compétences recherchées sur le marché du travail ont sensiblement changé au cours des vingt dernières années. Du fait de la restructuration de l'économie, le marché de l'emploi est de plus en plus fondé sur la connaissance. Le système d'enseignement s'est adapté à cette évolution structurelle, mais dans la mesure où le rythme de cet ajustement a été relativement lent, de nombreux diplômés restent privés de compétences adéquates et insuffisamment préparés à appliquer leurs connaissances dans des situations qui ne leur sont pas familières. En outre, la sélectivité forte et précoce qui caractérise le système éducatif accentue l'influence du milieu socioéconomique des élèves et des étudiants, ce qui se traduit par un excédent de travailleurs peu qualifiés dont les perspectives d'emploi sont médiocres. Cela contribue à la faiblesse persistante des taux d'emploi et des gains de productivité, ce qui ralentit le processus de convergence des revenus. Il faut améliorer les résultats du système d'enseignement, en assurant une meilleure correspondance entre les qualifications acquises et les besoins du marché du travail. Une amélioration globale des résultats du système d'enseignement le rendrait également plus équitable et inclusif. Pour renforcer l'offre de main-d'œuvre qualifiée, il faut s'appuyer sur la formation tout au long de la vie et améliorer l'accès au marché du travail des personnes ayant quitté le système scolaire sans compétences adéquates. Cela se traduira par un développement de la formation « en cours d'emploi », qui est un vecteur essentiel d'acquisition de compétences après l'achèvement de la formation initiale. En outre, mobiliser les ressources en main-d'œuvre qualifiée inexploitées, en particulier les femmes jeunes ayant reçu une formation, permettrait de rehausser le taux d'emploi, ce qui est nécessaire pour s'attaquer au problème que représente le vieillissement démographique pour le marché du travail.

Ce Document de travail se rapporte à l'Étude économique de l'OCDE de la Hongrie 2016

(www.oecd.org/fr/eco/etudes/etude-economique-hongrie.htm).

Classification JEL: I23; I25; I28; J48

Mots clés: Compétences, formation professionnelle, formation, marché du travail, politiques actives du marché du travail. 


\section{TABLE OF CONTENTS}

Economic restructuring has changed the labour market's skill requirements.........................................

The education system's reaction to structural changes has not been sufficient... ................................

...while structural problems on the labour market remain unsolved...................................................10

Future changes in labour demand are likely to increase the need for skilled labour.............................11

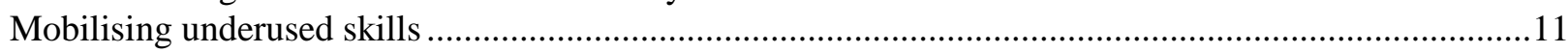

Increasing the supply of skills by enhancing women's labour market participation..............................11

Upgrading skills of elderly in order to increase their labour market participation...............................16

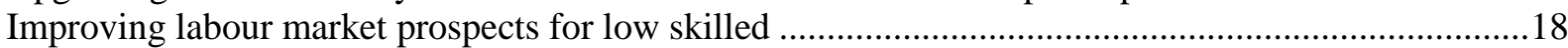

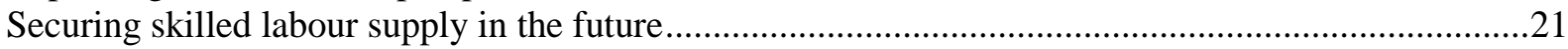

Securing future skills formation that meet the labour market needs ......................................................22

Enhancing the quality of learning and strengthening skills valued in the labour market......................24

Selectivity in education is hampering the basis for skills formation .....................................................26

Vocational training provides narrow labour market skills .................................................................27

Tertiary education must be more responsive to the labour market needs ..............................................30

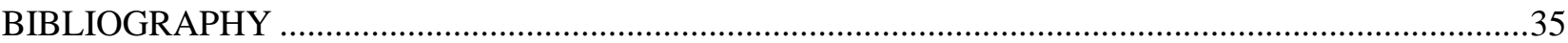

\section{Tables}

1. Payable public charges of employers offered by the Job Protection Act …....................................16

\section{Figures}

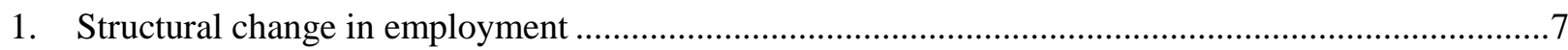

2. The room for further expansion in tertiary education remains high ..............................................

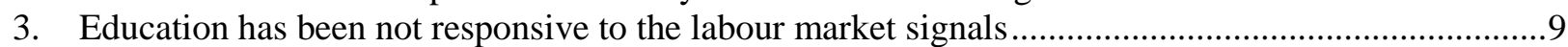

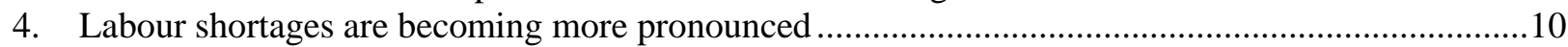

5. Female employment rates are low at both ends of the age distribution.......................................12

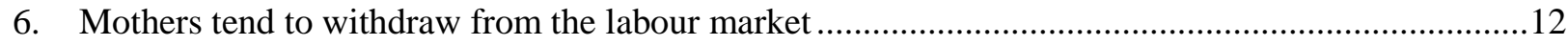

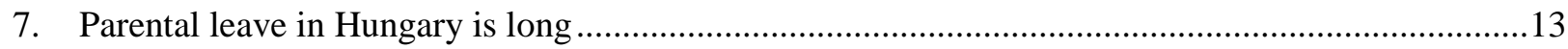

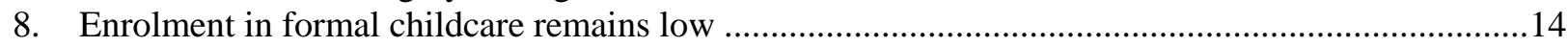

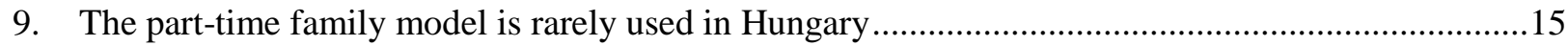

10. The less educated have lower chances of finding a job ............................................................18

11. Public work scheme jobs are predominantly in regions with high long-term unemployment.........19

12. Labour market status 6 months after participating in public work schemes .................................20

13. Emigration is low, but has been increasing significantly over recent years................................22

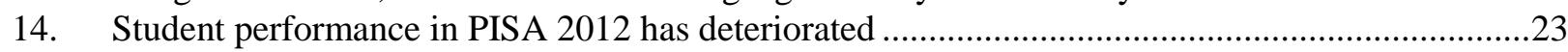

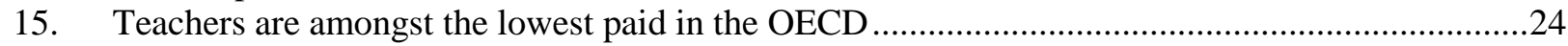

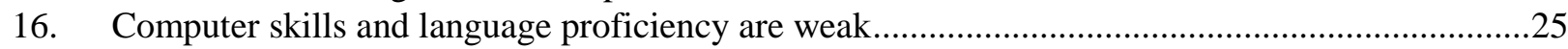

17. School enrolment and graduation rates of minority groups remain poor in Hungary ......................26 


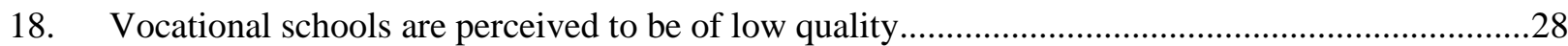

19. Labour market outcomes of Vocational school graduates are unsatisfactory ...............................29

20. Graduation rates can be significantly increased through raising completion rates .........................31

21. Difference in income and labour market outcomes by field of education ..................................31

22. Private returns on tertiary education are high in Hungary ...........................................................32

23. Students are not entering fields where labour market demand is high.........................................33

\section{Boxes}

Box 1 The Job Protection Act to promote employment growth .....................................................16

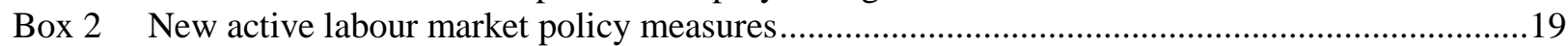

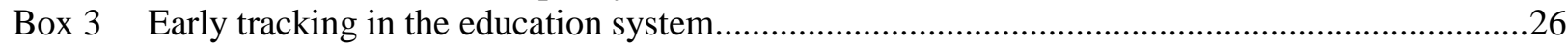

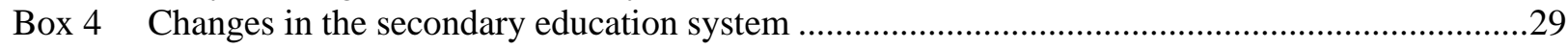

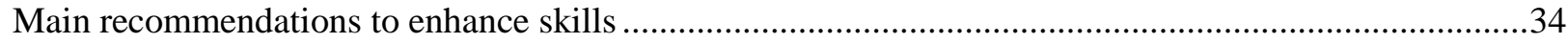




\section{ENHANCING SKILLS TO BOOST GROWTH IN HUNGARY}

\section{By Gabriel Machlica ${ }^{1}$}

\section{Economic restructuring has changed the labour market's skill requirements}

The structure of the economy has undergone marked changes over the past two decades. The service sector has expanded, particularly in business and retail services (Figure 1, Panel A). In addition, new jobs have appeared in information technologies and telecommunication services. At the same time, manufacturing has become more tightly integrated into global value chains and more concentrated in sectors with a higher technology content, moving away from heavy industries to electrical and transport equipment industries (Figure 1, Panel B). Over the same period, employment in agriculture, mining, textiles has plummeted.

The restructuring led to important changes in terms of occupational structure and skill requirements. The overall skill content has increased, with a growing share of workers with tertiary and college education (Figure 1, Panel C). Over the past two decades, growth in professional and technical occupations has increased more than employment in other occupational categories. In addition, ICT related occupations have spread throughout the economy. In contrast, job opportunities for unskilled workers have significantly declined and the share of craft physical workers has decreased. This trend is in line with the experience in other European countries, where the blue collar occupations saw the most pronounced declines and the demand for craft skills and repetitive physical tasks declined significantly (Handel, 2012). At the beginning of the transition period the share of low skilled job was two to three times higher than in western economies (Kollo, 2006). The restructuring has led to a large excess of low-skilled supply and the relative wages of workers with higher education have dramatically improved, leading to wide wage gap between low and high skilled workers (Figure 1, Panel D).

\footnotetext{
${ }^{1}$ Gabriel Machlica is an economist in the Country Studies Branch (e mail: gabriel.machlica@oecd.org) in the Economics Department of the OECD. The author is grateful to numerous OECD Economics Department colleagues for their valuable comments, including Pierre Beynet, Jens Høj, Robert Ford and Alvaro Pereira. The report also benefited from comments from the Hungarian authorities and Edit Huszár, seconded from the Hungarian Ministry of the National Economy. Taejin Park and Anthony Bolton (also from Economics Department) provided excellent research, statistical and editorial support.
} 
Figure 1. Structural change in employment

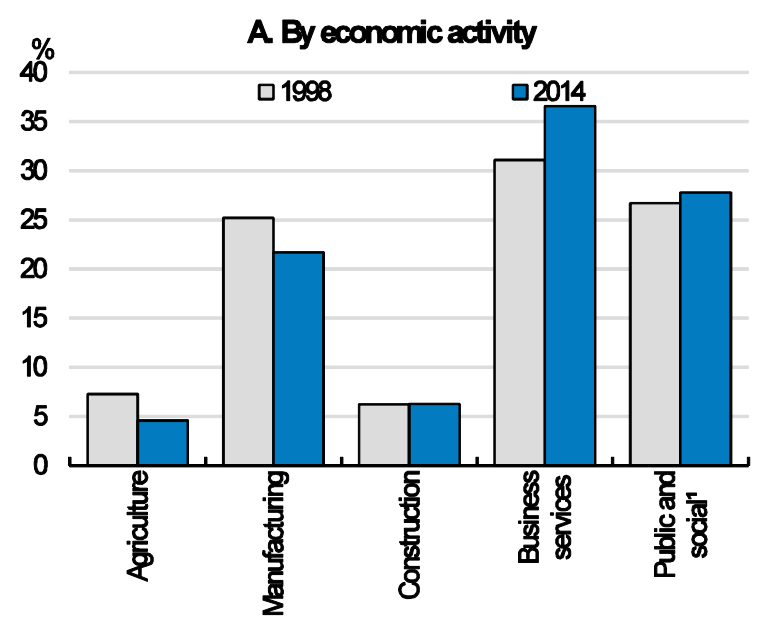

B. Manufacturing by technological intensity ${ }^{2}$

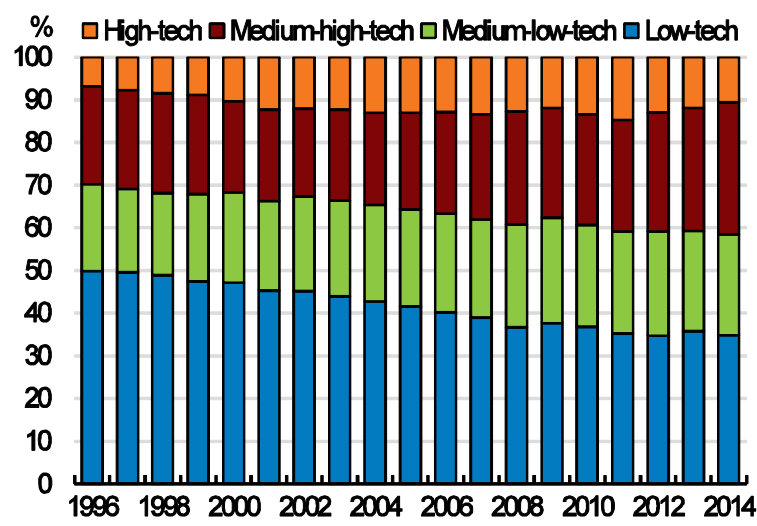

C. By highest education qualification

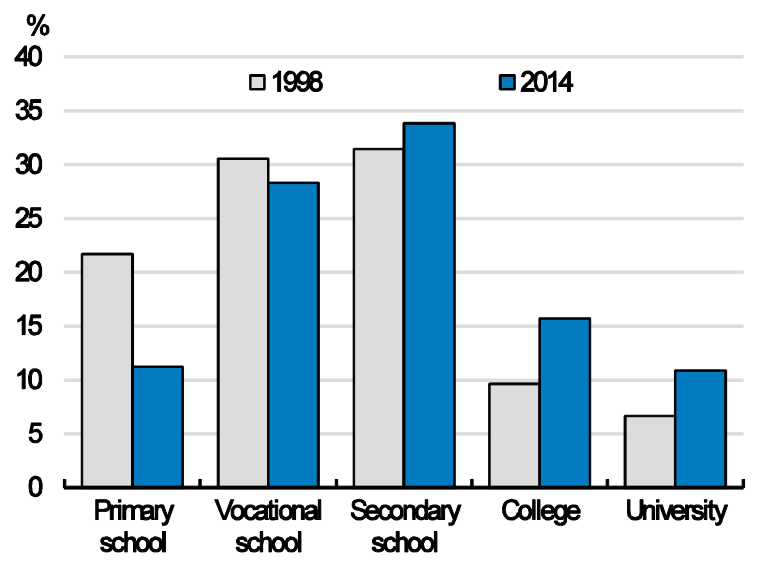

D. Wages by highest education qualification (average $=100)$

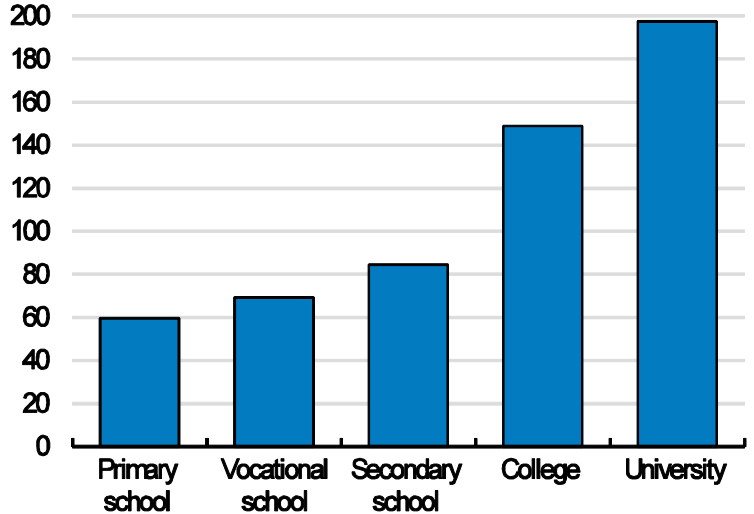

1. Public administration and defence; compulsory social security; education; human health and social work activities; other service activities.

2. Manufacturing technology intensity is an aggregation of manufacturing industries according to technological intensity (R\&D expenditure/value added) and it is based on the Statistical classification NACE at 2-digit level according to Eurostat High-tech classification of manufacturing industries.

Source: Eurostat, Employment-LFS series database; Hungarian Central Statistical Office, Labour Market Statistics.

\section{The education system's reaction to structural changes has not been sufficient...}

The population's educational attainment has increased considerably over the past couple of decades. Enrolment rates in secondary education have increased from 64\% in 1995 to $92 \%$ in 2013 . As a result, the proportion of the population with at least upper secondary education is $60 \%$, well above the OECD average of $44 \%$. However, the improvement in education attainment is relatively recent and many older workers have a low education attainment. This highlights the importance of an efficient system of life-long learning to develop skills for this part of the population. 
Enrolment in tertiary education has nearly quadrupled since 1991, boosting enrolment rates among the youth aged 20-29 to 26\%. However, higher enrolment has not resulted in higher graduation rates, which at $23 \%$ is much lower than the OECD average. As a result, the stock of graduates remains relatively low, allowing them to command one of the highest wage premiums in the OECD. In addition, the unemployment rate for graduates is $3.7 \%$, half of the national average (Figure 2).

Figure 2. The room for further expansion in tertiary education remains high

Relative earnings of tertiary-educated workers and their share in the population, 2013 or latest available data

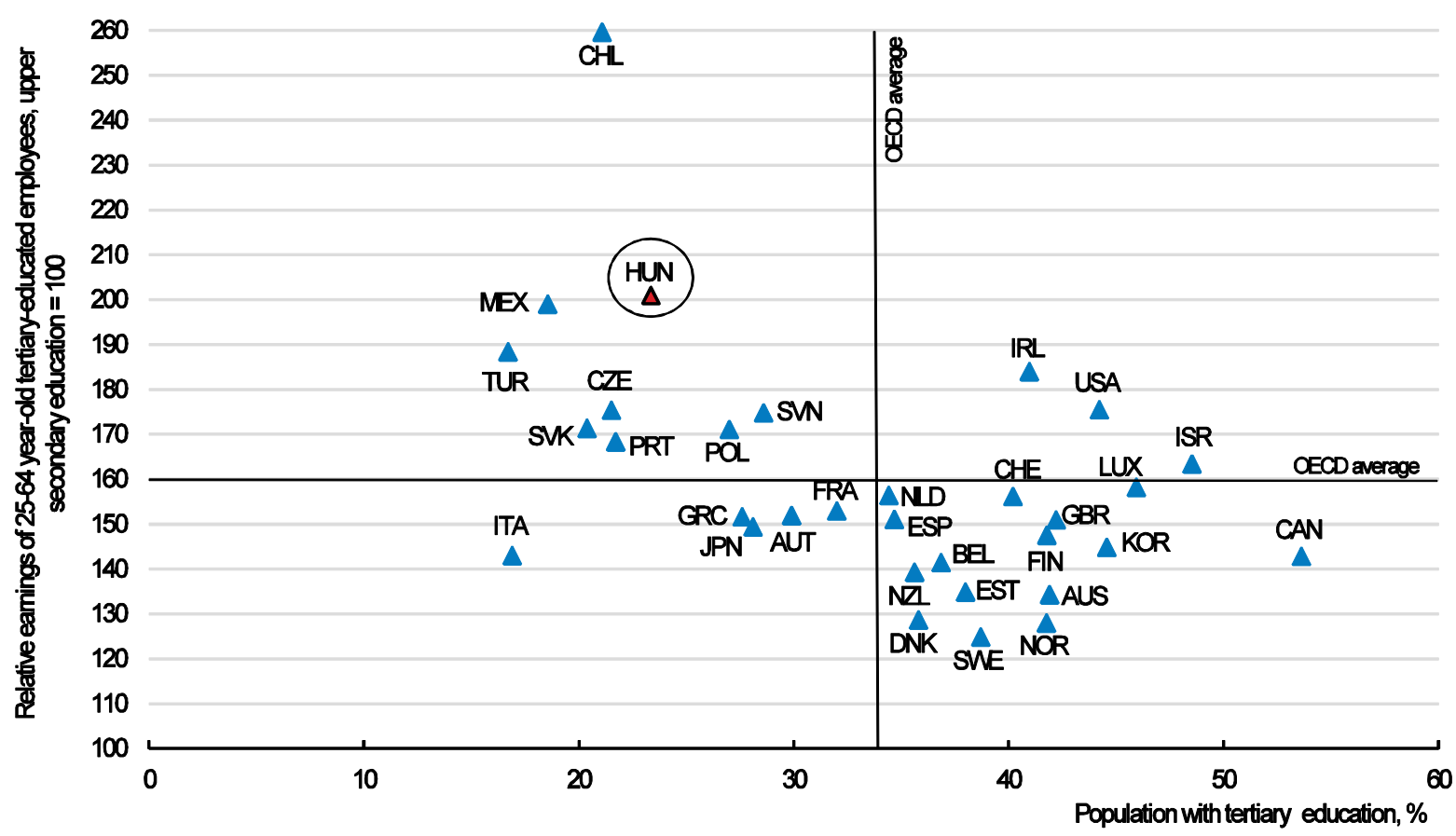

Note: Tertiary education includes short cycle tertiary, bachelor's, master's, doctoral or equivalent degrees. Data on educational attainment refers to year 2014 or latest available year.

Source: OECD (2015), Education at a Glance 2015, Tables A1.3a and A6.1a.

Overall participation in education reflects higher demand for skills, but it seems the content of education and fields of studies have adjusted much more slowly. Indeed, graduation rates have increased in fields where employment rates are relatively low (Figure 3, Panel A). This translated into growing mismatches with a high share of the workforce occupying a position not directly related to their field of study (Figure 3, Panel B). A better match between people's skills and occupations, implying a better use of talent could boost labour productivity by as much as $10 \%$ (McGowan et al., 2015). 
Figure 3. Education has not been responsive to labour market signals
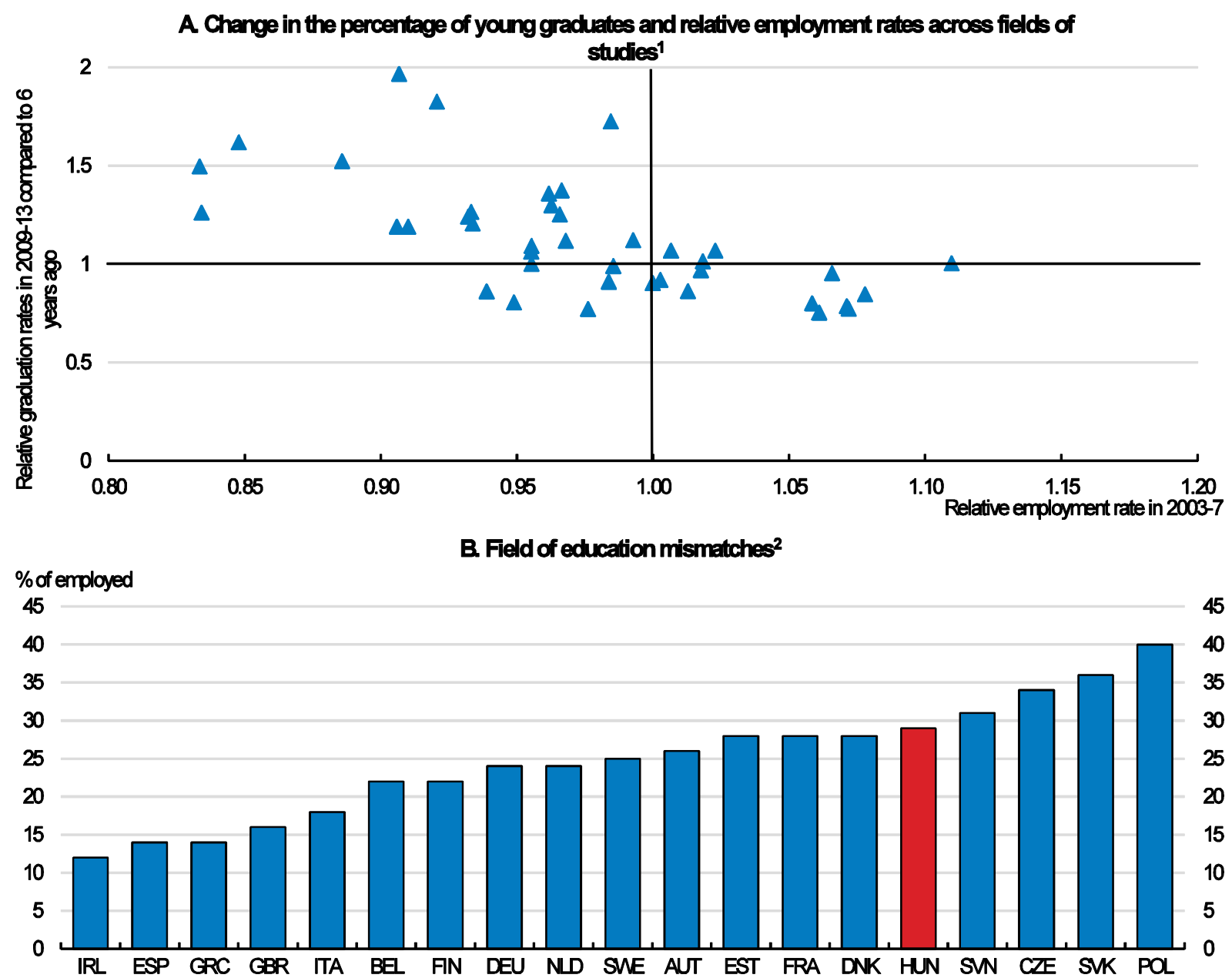

1. The average growth in the percentage of graduates from each field is calculated over employed youth (aged 15-29) considering graduates from specific fields (excluding youth who graduated from "General Programmes") over the period of 2003-9, 2004-10, 2005-11, 2006-12 and 2007-13. The relative employment rate, considering the entire population, is calculated as the ratio of the employment rate for graduates from each field (irrespective of whether they work in the field or not) and the employment rate of the entire population. Relative employment rates above 1 mean that the employment rate among graduates from that field is higher than the national average; values below 1 mean that the employment rate of graduates from that field is lower than the national average.

2. Field of education mismatches take place when the level of education matches job requirements but the type of education (e.g. field of study) is inappropriate for the current job. 2009 data.

Source: OECD calculations based on the European Labour Force Statistics 2003 - 2013; Randstat (2012), "Into the Gap: Exploring Skills and Mismatches", SEO Report, No. 2011-56, SEO Economic Research.

Another sign of insufficient skills creation is that companies are increasingly experiencing shortages of skilled labour and to a higher degree than in other Central and Eastern European countries (Figure 4, Panel A). The main reasons are lack of job applicants with relevant technical competences. The labour shortages are more pronounced in manufacturing, affecting over half of all companies and particularly among large export companies (Figure 4, Panel B). Overcoming skills shortages could enable firms to meet growing demand and boosting income creation. 
Figure 4. Labour shortages are becoming more pronounced

A. Skill shortages in selected countries', 2015

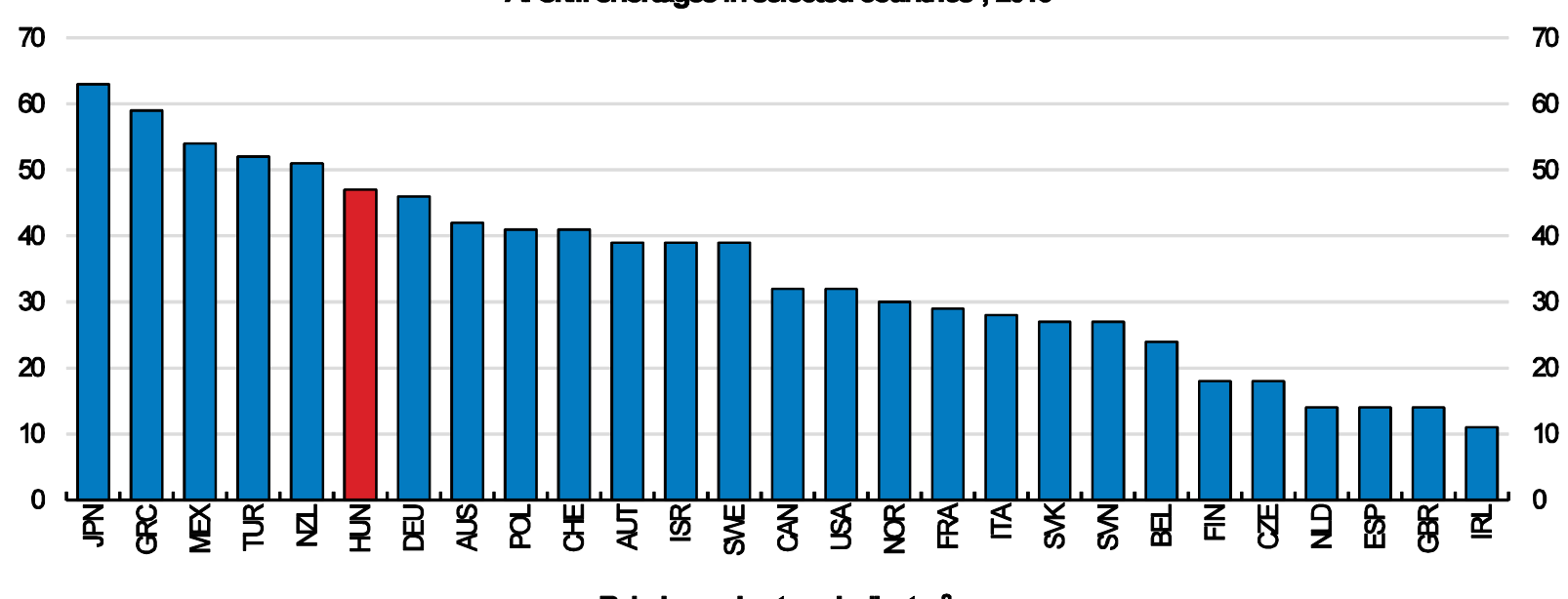

B. Labour shortage Indlcator ${ }^{2}$

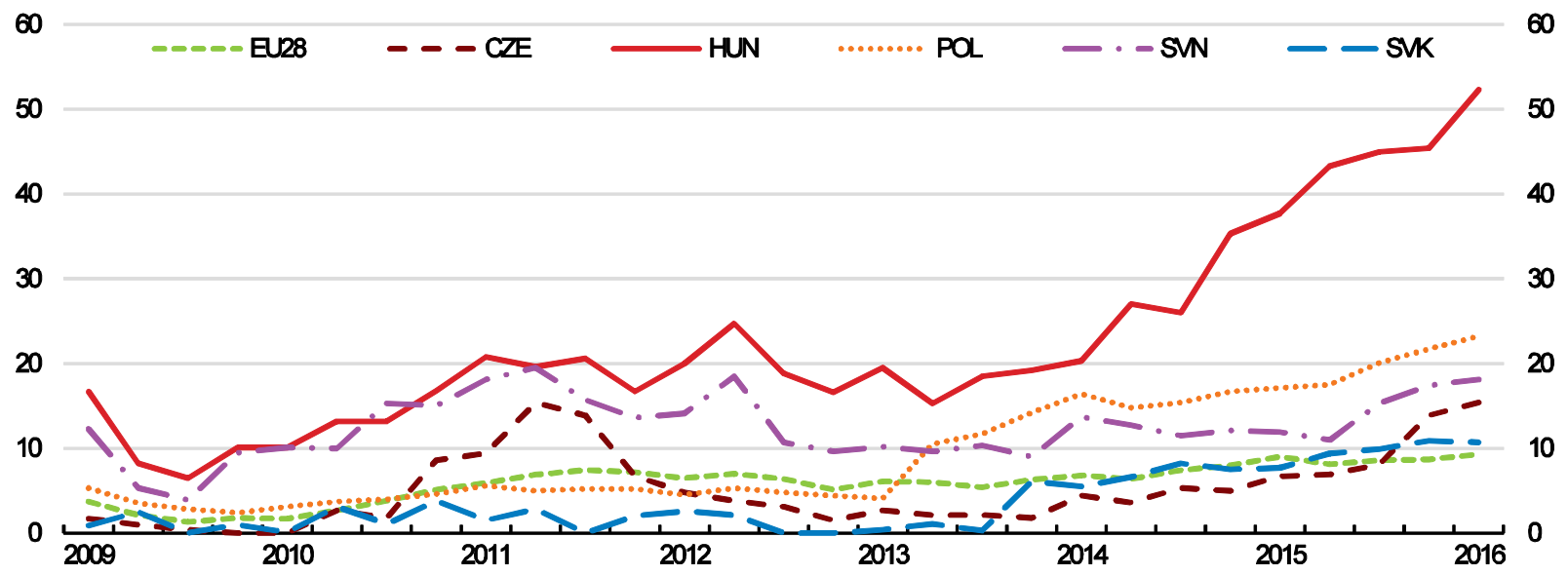

1. As a percentage of all firms with 10 or more employees. Firms are classified as facing a skill shortage if their manager reports having difficulties filling jobs.

2. Percentage of manufacturing firms pointing to labour shortage as a factor limiting production.

Source: Manpower Talent Shortage survey (2015); Eurostat, Industry database.

\section{...while structural problems on the labour market remain unsolved}

The changes in education outcomes have not bolstered the internationally low employment rates. Despite high enrolment in secondary education, the employment rate for youth age 20-24 remains below the OECD average. This suggests that the changes in the education system have not sufficiently matched the skills of younger generation exiting the education system with labour market needs. Thus, little progress has been made in solving persistent structural problems with low employment rates.

Long-term unemployment remains high, with $50 \%$ of the unemployed out of the labour market for more than a year, and this mostly affects workers with poor and obsolete skills. The difference in labour market outcomes between low-skilled and high-skilled workers is one of the largest in the OECD (OECD, 2014a). For example, average job searching time of low-skilled unemployed is 15 weeks longer than the average search time, contributing to high long-term unemployment. Moreover, long-term unemployment has an important regional dimension, where regions with high unemployment are also those with higher share of long-term unemployed. 


\section{Future changes in labour demand are likely to increase the need for skilled labour}

Looking ahead, the labour market is likely to demand workers with high skill levels. Income convergence in itself implies higher wages and a move up the value added chain, requiring a more skilled labour force. In addition, further integration into global value chains is likely to bolster demand for skills. Furthermore, the changing economic structure, with a higher reliance on the service sector, is likely to create new job opportunities for well-educated professionals with qualifications in science, engineering and health (EC, 2015a).

The ongoing ageing process means that the labour force is expected to shrink. Thus, the income convergence process will become ever more dependent on securing successful educational outcomes for shrinking youth cohorts. In addition, the older and growing part of the workforce will have occupation specific experience. This raises the risk of rapid technological change, which will lead to fast depreciation of skills, raising demands on life-long learning and out-of-job training to maintain human capital (Braconier, Nicoletti and Westmore, 2014).

\section{Mobilising underused skills}

Underutilised labour sources and the effects of population ageing can be countered by upgrading skills and boosting employment rates of under-represented groups in the labour market. Increasing employment rates will amplify the chances of "on-the-job learning", which is one of the main drivers for acquiring skills after graduation. The low employment rate is mainly attributed to a few partly overlapping groups: i) women in child bearing age; (ii) low skilled persons; and (iii) older workers. Bolstering participation of these groups on the labour market combined with measures to attract and retain skilled migrants can help secure a more skilled labour supply.

\section{Increasing the supply of skills by enhancing women's labour market participation}

Women's skills are underused in Hungary. The employment rate of females remains relatively low in certain age groups despite increased job opportunities in service sectors (Figure 5). This is worrying given that females account for nearly two-thirds of new tertiary graduates. Low female participation and employment is particularly pronounced at both ends of the age spectrum. The employment rate of older females has increased in reaction to the tightening of conditions of old-age pension and disability retirement (Kátay and Nobilis, 2009). On the other hand, participation of younger women remains low, reflecting higher educational enrolment and labour market withdrawal related to parental responsibilities.

Although the employment of mothers with children increased in recent years, the impact of motherhood in reducing female labour market participation remains among the highest in the OECD (Figure 6). This reflects that mothers with small children are faced with high work disincentives, such as a lack of childcare supply. Thus, young women are often faced with a choice between employment and parenthood, reducing female labour participation and also contributing to one of the lowest fertility rates (1.41 children per woman) among OECD countries. Moreover, when workers stay out of the labour market for extended periods of time, their human capital will deteriorate, this may contribute to the fact that tertiary educated women in Hungary earn only two-thirds that of their male counterparts. 
Figure 5. Female employment rates are low at both ends of the age distribution

Female employment/population ratio by age group, 2014

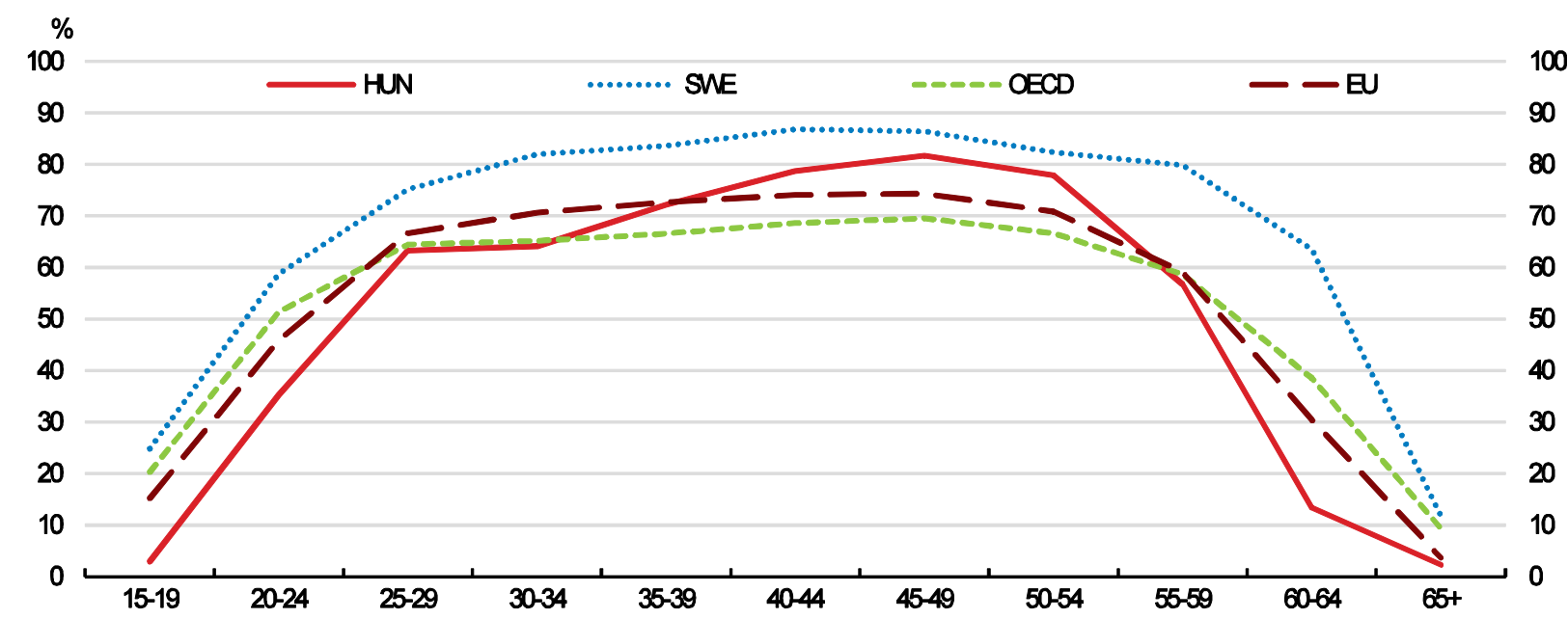

Source: OECD (2015), Labour Force Statistics (database).

Figure 6. Mothers tend to withdraw from the labour market

Difference between employment rates of women 20-49 with children up to 6 years old, and without children, 2012 Percentage point

10

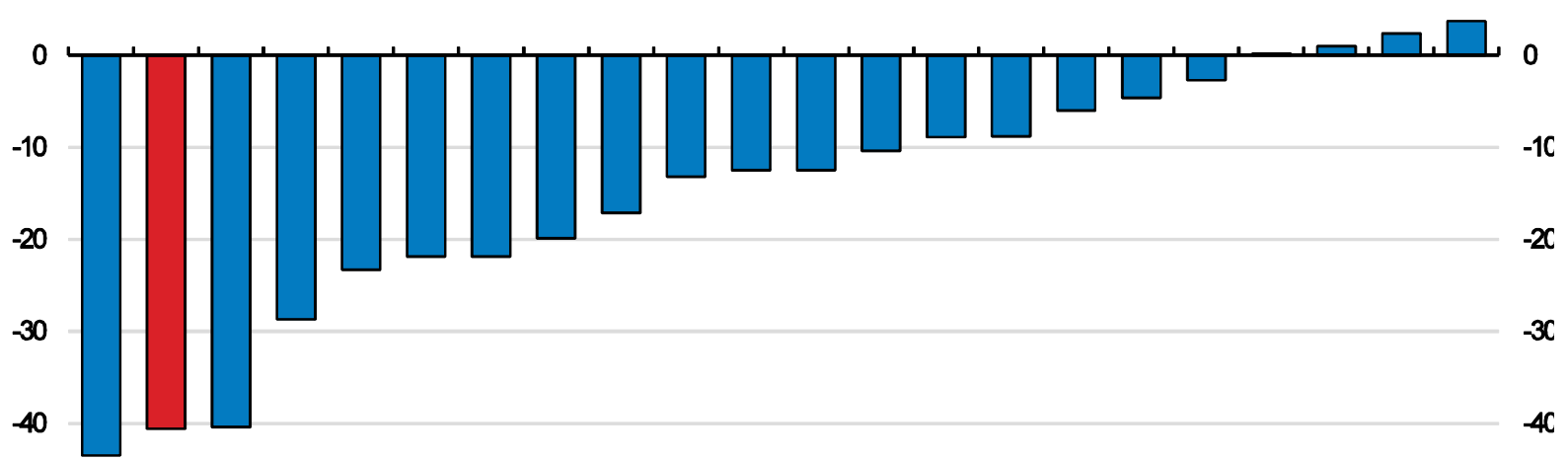

-50 CZE HUN SWK EST DEU TUR GBR IRL FN POL LUX AUT TTA FRA ESP BE ND GRC SVN PRT DNK SWE

Note: Negative values indicate that employment rates of those with children up to 6 year olds are lower than those without children. Source: Eurostat. 
Mothers with young children typically take long periods of parental leave. This pattern is similar across countries in the region, reflecting a tradition for comprehensive and long maternity leave policies and guaranteed jobs upon return. Attitudes are slowly changing, but still more than $80 \%$ of survey respondents believe that pre-school children under age three suffer if their mothers work (Buber-Ennser, Panova 2014). However, these attitudes also reflect a lack of family-friendly work opportunities and serious shortages of childcare services (Blasko, 2011). Hungary has one of the longest parental leaves in the OECD, which is almost exclusively taken by the mothers (OECD, 2012a; Figure 7). Longer parental leave is supported by generous family policies. The mother is entitled to 24 weeks maternity leave and receives maternal benefits in the amount of $70 \%$ of her previous salary. Thereafter a parent is allowed to take up to three years of parental leave and receive parental benefits up to $70 \%$ of twice the minimum wage until the child becomes two years old. Between the second and third year of the child the parental benefit equals the sum of the minimum elderly pension.

\section{Figure 7. Parental leave in Hungary is long}

Weeks of paid parental and home care leave, 2014

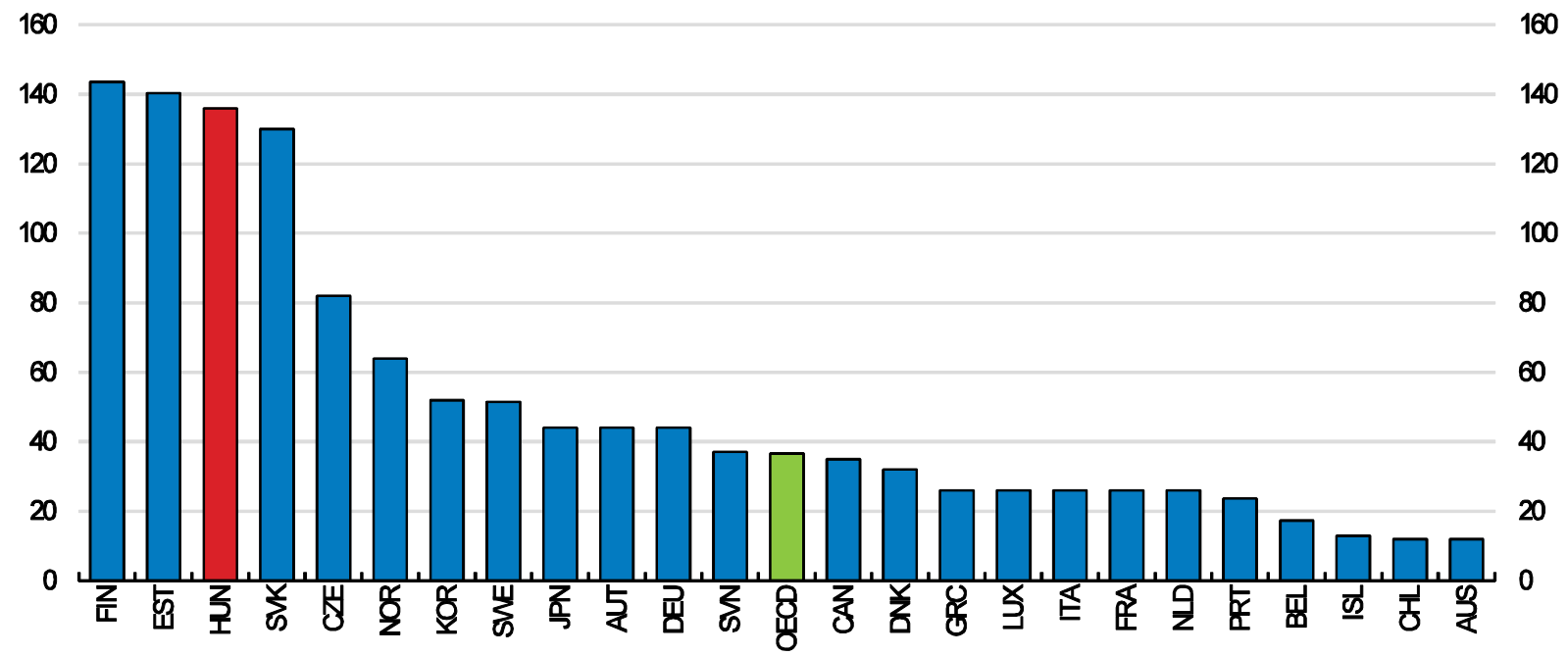

Source: OECD (2015), OECD Family Database.

Child care facilities remain scarce. This can be explained by the closing of state owned company run child-care facilities in early 1990s, which halved the number of available places. Despite significant improvements in the past years these places have not been adequately replaced. The number of child care facilities (crèches) has started to increase in recent years, as a part of the government's strategy to increase parents' labour participation. However, still only $16 \%$ of small children attend nurseries (Figure 8). The intake in Kindergartens (children above 3 years) is much higher, with 10 times more places available, although in this respect major cities are experiencing capacity constraints. When securing a place, parents are faced with the additional hurdle of opening hours, which are not aligned with working hours (Herrmann et al., 2014). To further expand child care supply, part of the parental leave benefits can be mandated towards support of childcare facilities through a voucher linked to the purchase of childcare services; this could stimulate private sector provision of childcare (OECD, 2007). 
Figure 8. Enrolment in formal childcare remains low

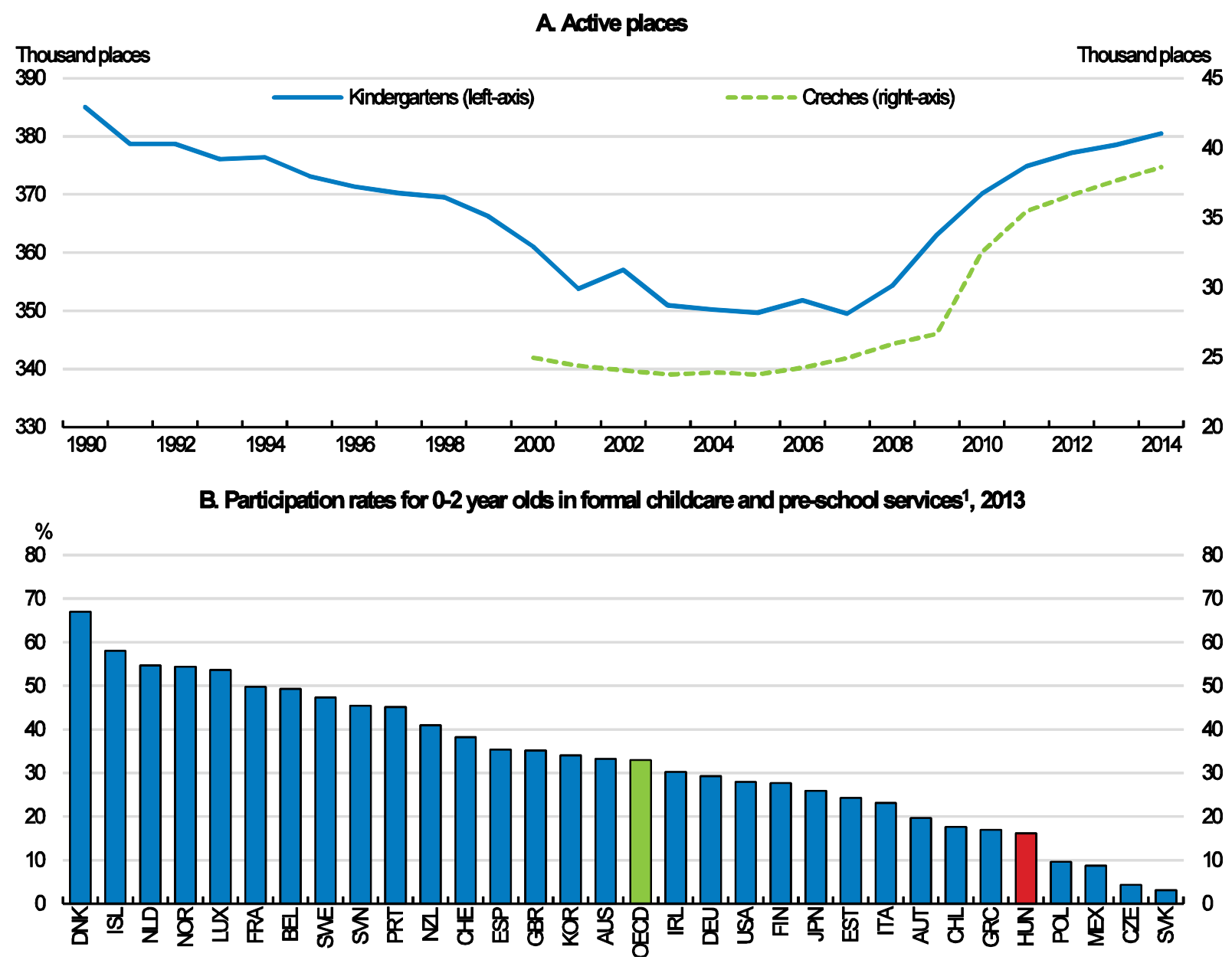

1. Data reflect children in day-care centres and pre-school (both public and private) and those who are cared for by liscensed childminders. It excludes informal services provided by relatives, friends or neighbours regardless of whether or not the service is paid for.

Source: Hungarian Central Statistical Office; OECD (2015), Family Database.

Part-time work and flexible working arrangements could facilitate combining work and family responsibilities, but are rarely used as the female part-time ratio is just $6 \%$, low by international standards (Figure 9). To promote flexible employment, resources from European funds have been redirected to support flexible employment and the demand for part-time workers is further supported by reduction in social security contributions (Box 1). This has been combined with the introduction of family-friendly practices and adequate training for human resources professionals and managers. Further steps are necessary to promote the use of part-time employment. The government can increase women's part-time work in the public sector providing an example for the private sector and thus improving female labour market participation. At the same time, the choice between full-time and part-time work should be neutral to ensure that women have easy access back to full time jobs. 
Figure 9. The part-time family model is rarely used in Hungary

Employment patterns among couple families with children aged 0-14, $2011^{1}$

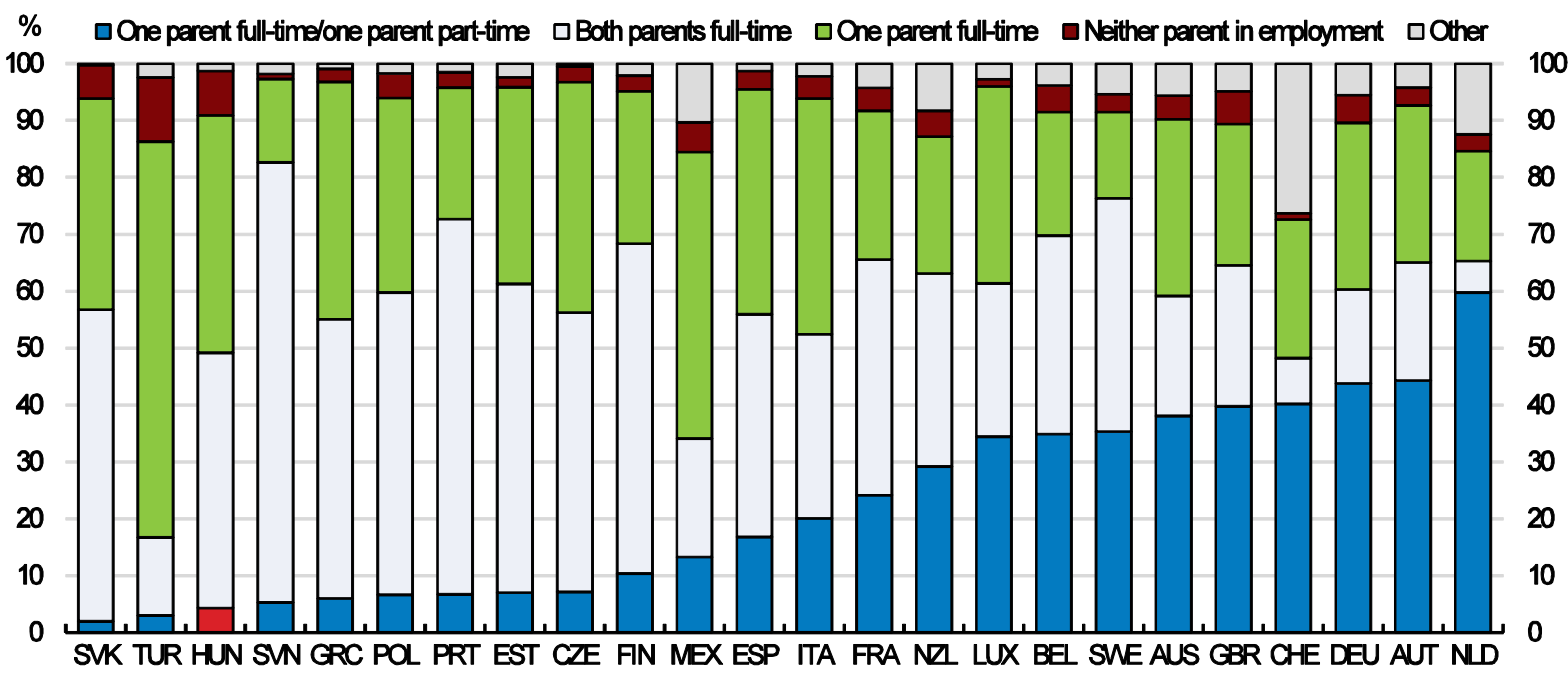

1. 2010 data for Mexico, Sweden and Switzerland.

Source: OECD (2014), OECD Family Database.

The government has recognised the problem and has taken several steps to improve female access to the labour market, including permitting the parents to work without losing the entitlement to the parental allowance and child-care allowance. The government also provides tax credits for employers hiring parents with young children (Box 1). Moreover, the government introduced measures that oblige employers to allow returning mothers to work part-time until their children reach the age of three. This measure, however, should be monitored carefully as evidence from Spain showed that similar policies of protection of mothers against layoffs decreased hiring of women in child bearing age (Rodríguez-Planas and Fernández Kranz, 2013).

So far, these measures have not overcome prevailing negative attitudes towards working mothers. To do so, a gradual reduction of the parental leave period and increasing the role of fathers could further increase mother's participation in the labour market and promote a more gender balance sharing of paid and unpaid work. Reductions in parental leave could be done by shortening child-related leave entitlements, but paying them at a higher rate. In Germany the flat-rate childcare payment for 22 months was reformed into an earnings-related income-support payment over 12 months. This could be combined with an increase in paternity leave by transforming part of the family entitlements available to both partners into individual non-transferable rights for the specific use of fathers. A reform such as this in Iceland increased the proportion of parental leave days taken by fathers from $3 \%$ to around $35 \%$ (OECD, 2011a). In addition, empirical research suggests that increasing the role of father in child care is associated with rising fertility rates and has the potential to be beneficial for the child development later in life (Feyer et al., 2008; Cools et al., 2015). 


\section{Box 1 The Job Protection Act to promote employment growth}

The government introduced the Job Protection Act in 2013 to promote employment in private sector and ease administrative burdens of employers.

An important part of the measures are aimed at strengthening labour demand for workers with weak links to the labour market such as people under the age of 25 or over 55, long-term job-seekers, workers in unskilled jobs, agricultural employees and mothers with small children returning to work. A reduction in social security contributions and vocational training subsidies are offered to employers, who are hiring hard-to-employ workers. To create and preserve existing jobs, these tax allowances can be taken in the case of both newly employed and current workers.

The Job Protection Act significantly reduced social security contributions. With a gross wage of up to HUF 100000 , the overall $28.5 \%$ of social security contributions payable by the employer is lowered to $14 \%$, when companies employ people under the age of 25 , over 55 or workers in unskilled jobs. Furthermore, in the first two years of employment, enterprises are totally exempt from social security contributions in the case of career starters (under 25, with at least 180 days of work experience), long-term job seekers (registered as unemployed for over 6 months) and mothers with small children (after having received child care fees or after/during their eligibility for child care allowance or child raising support). Also, in the third year of employing long-term job seekers or mothers, the employer social security contributions are lowered to $14 \%$.

Table 1. Payable public charges of employers offered by the Job Protection Act

\begin{tabular}{|c|c|c|c|c|}
\hline \multirow[b]{2}{*}{ Beneficiary groups } & \multicolumn{4}{|c|}{ Payable public charges of employers up to HUF 100000} \\
\hline & & $\begin{array}{l}\text { Social security } \\
\text { contribution }\end{array}$ & $\begin{array}{l}\text { Vocational training } \\
\text { contribution }\end{array}$ & Total \\
\hline \multicolumn{2}{|l|}{ Under the age of 25} & $12.5 \%$ & $1.5 \%$ & $14.0 \%$ \\
\hline \multicolumn{2}{|l|}{ Over the age of 55} & $12.5 \%$ & $1.5 \%$ & $14.0 \%$ \\
\hline \multicolumn{2}{|l|}{ Agricultural employees } & $12.5 \%$ & $1.5 \%$ & $14.0 \%$ \\
\hline \multirow{2}{*}{$\begin{array}{r}\text { Career starters } \\
\text { (with max. } 180 \text { days of work experience) }\end{array}$} & first 2 years & $0.0 \%$ & $0.0 \%$ & $0.0 \%$ \\
\hline & 3rd year & $12.5 \%$ & $1.5 \%$ & $14.0 \%$ \\
\hline Long-term job-seekers & first 2 years & $0.0 \%$ & $0.0 \%$ & $0.0 \%$ \\
\hline Mothers with small children ( 1 or 2 children) & 3rd year & $12.5 \%$ & $1.5 \%$ & $14.0 \%$ \\
\hline \multirow{2}{*}{$\begin{array}{l}\text { Mothers with small children ( } 3 \text { or more } \\
\text { children) }\end{array}$} & first 3 years & $0 \%$ & $0 \%$ & $0 \%$ \\
\hline & 4 and 5 years & $12.5 \%$ & $1.5 \%$ & $14.0 \%$ \\
\hline
\end{tabular}

Source: National Employment Service of Hungary

\section{Upgrading skills of elderly in order to increase their labour market participation}

Population ageing has brought the share of 55-64 year olds in the population to $21 \%$, which is one of the highest among OECD countries. Since the crisis, this age cohort's employment rate has shot up as the government tightened conditions for receiving old-age and disability pensions, and increased labour demand incentives with new tax measures devoted to this age group (Box 1). Nonetheless, the employment rate of those above 55 is still only $40 \%$ - the third lowest in the OECD. Despite, the participation of future older workers is expected to increase in line with rising educational attainment, and thus skill-enhancing measures are needed to increase employability of recent older workers. 
Moreover, the demand for different skills is subject to constant change. This means that older workers are particularly exposed to a depreciation of their qualifications in the absence of continuous investment in education and training. In this context, training can preserve their skills and increase their employability. However, the participation of older workers in lifelong learning is low compared to other countries. Training provided by companies is one of the lowest amongst EU countries and incentives have decreased further as the possibility of deducting the training costs from social contributions was eliminated in 2012 (Eurofound 2015). A low incidence of lifelong learning could contribute to relatively low employment rate of older workers (OECD, 2012a). Therefore it is important to promote policies encouraging upgrading of skills, particularly targeted at older workers, and also encourage informal learning within the firm.

Firms may find it less profitable to train older workers as they are approaching retirement, therefore public support should be tilted towards individual take-up incentives. For example, the current vocational training contribution (1.5\% of wages) could be used to create individual learning accounts. Experiences in other OECD countries, such as Canada, Netherlands, and Spain, indicate that individual learning accounts can be effective in facilitating lifelong learning. The advantage of such accounts is that they provide individuals with a training subsidy that give them more responsibility and control, allowing for a better match between the individual needs and appropriate training. An alternative or complementary approach could be offering training vouchers targeted at older workers. In Austria, adult courses are subsidised by vouchers whose amount varies according to the characteristics of adults (OECD, 2005a).

Programmes designed combining short classroom sessions with a firm-based approach, could be effective for older workers. Foundation of general skills becoming relatively less important as people grows older. After a certain age, the benefit that a person can reap from specific job-related training is higher than the return on investments in more general skills, whose pay-back period can be relatively long as compared with the remaining working life of that person.

In order to avoid skills depreciation policies to promote older worker participation should be strengthen. The government has already reduced the social security contribution for older workers paid by employers, which could improve their employability (see Box 1). Reducing the implicit tax on work at older ages would increase employment and promote training participation (Bassanini, 2005). In addition, empirical research shows wage subsidy program targeted at long-term unemployed aged over 50: is effective in reemploying older workers. (Cseres-Gergely et al., 2015). Wage subsidy programmes should be scaled-up and can be supplemented with job search assistance and job search monitoring measures. 


\section{Improving labour market prospects for low skilled}

The difference in employment rates between low-skilled and high-skilled workers is one of the largest in the OECD (Figure 10). Moreover, the long-term unemployed are characterised by inadequate and obsolete skills. This suggests that more is needed to assist low skilled adults that have left the education system without adequate skills.

\section{Figure 10. The less educated have lower chances of finding a job}

Employed persons as percentage of population, age 25-64, 2014
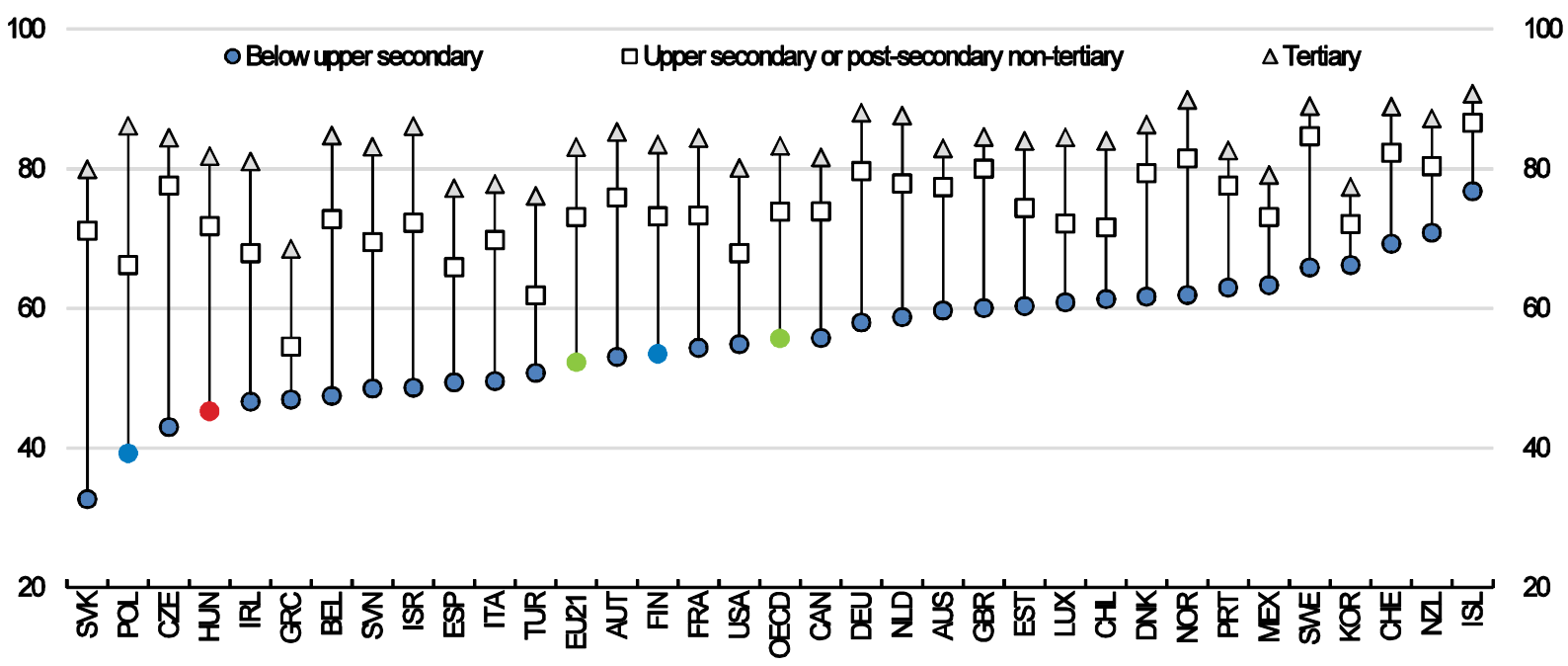

Source: OECD (2015), Education at a Glance 2015, Table A5.3a.

The government's main measure to alleviate the insufficient skill problem is high spending on active labour market policies (ALMP), mostly though the public works scheme. However, these programmes have little emphasis on skill enhancing measures. Spending on active labour market policies has more than doubled over the past 10 years to $0.8 \%$ of GDP in 2013 driven by a strong expansion in public works schemes, particularly since 2009 , which now accounts for $0.5 \%$ of GDP. In contrast, spending on training measures is lower than a decade ago. Besides these programmes, the government has recently introduced several active labour market policy measures to improve employability of certain group of job seekers (Box 2).

The public works scheme holds the promise of making growth more inclusive by providing low paid jobs to the unemployed. The programmes typically offer jobs in the public sector and intend to help the unemployed maintain basic general labour market skills, such as working discipline and time management. Currently $5 \%$ of overall employment is sourced in this type of jobs in the public sector, which are mostly provided in the poorer regions that have a higher share of long-term unemployed (Figure 11). Wages paid through the scheme amount to three quarters of the minimum wage and is paid by municipalities or state companies and subsequently reimbursed by the central government. A problem is that there is little supervision of how these funds are used. Thus, local municipalities have a strong interest in organising public works and expanding the available budget (Scharle, 2015). Other reason behind increasing participation in the public works scheme is relatively short duration of unemployment benefits, which has been reduced from nine months to three months in 2012. The public works scheme provides temporary relief to the unemployed. This helps to reduce social tensions and contribute to local community development. 


\section{Box 2 New active labour market policy measures}

The government has introduced several active labour market policy measures to improve employability of certain groups of jobseekers.

1. The "Path to work", is a large-scale active labour market programme which aims to improve the employability of jobseekers by personalized and tailor-made individual programmes including labour market services, subsidies and training. Priority target groups of the program includes low skilled, older people $(50+)$, career starters between 25-30, parents returning to the labour market after parental leave and those exiting from the public work scheme.

2. The Youth Guarantee system aims to ensure that young people (16-24) not in employment or education/training (NEET) are provided with a support to improve their chances on the primary labour market. The program offers entrepreneurship support, apprenticeship, traineeship, further education within 4 months after being registered in the Public Employment Service.

3. The start-up incentive program aims to support young people to set up their businesses through provision of entrepreneurial training, mentoring and development of business plans. Young people who complete their training and have their business plan accepted can apply for a maximum 10000 EUR grant to cover their initial costs.

4. An apprenticeship program fosters the employment of young qualified career starters by fully or partially subsidising their wages and social contributions for nine months.

\section{Figure 11. Public work scheme jobs are predominantly in regions with high long-term unemployment}

Rate of registered jobseekers over 180 days in working-age population, 2014

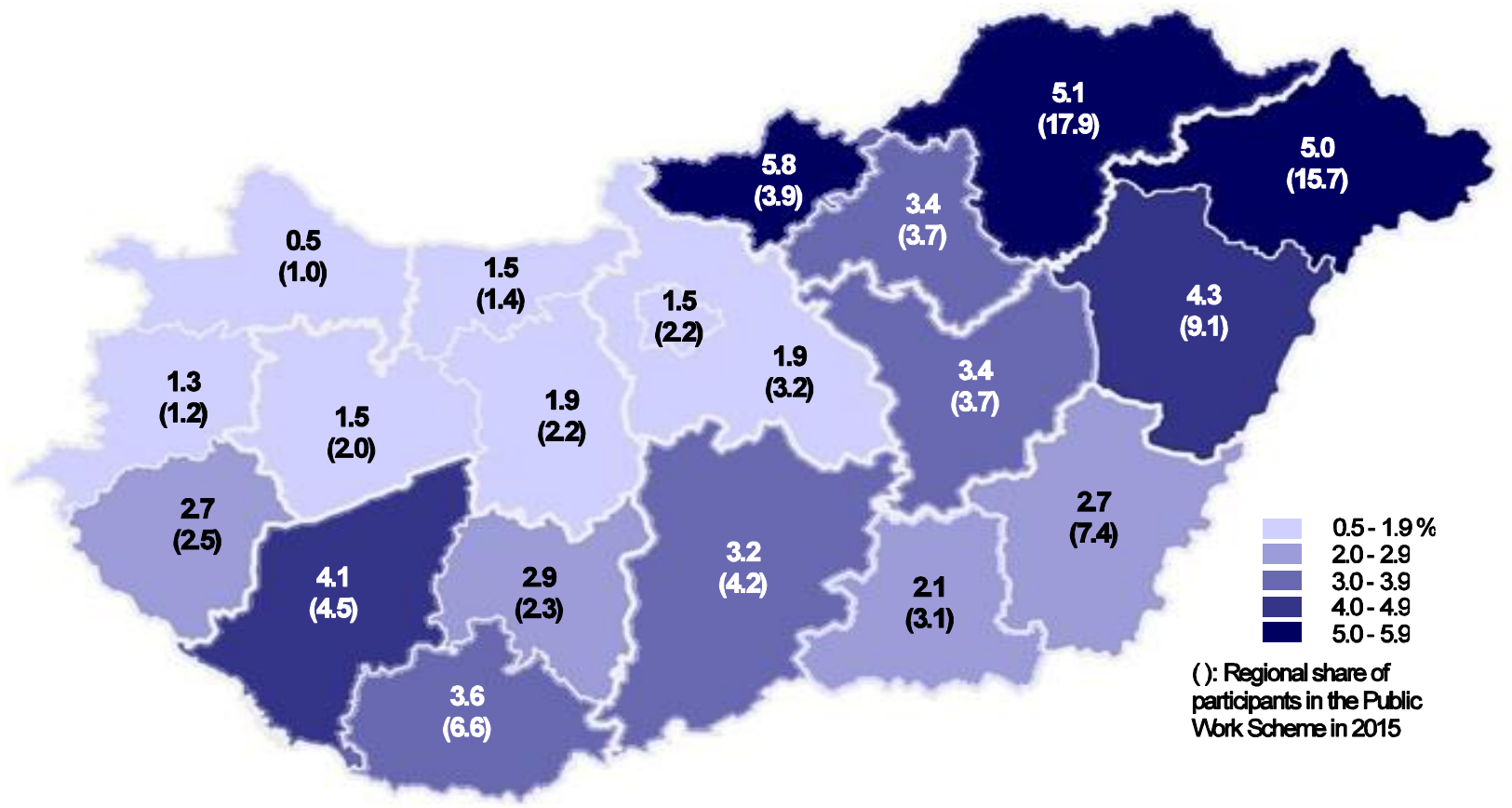

Source: Hungarian Central Statistical Office.

Only a small share of participants find a job in the private sector and most who exit out of the scheme tend to return to the program after 6 months of spell of unemployment (Figure 12). Repeated participation has particularly detrimental effects on skills and re-employment prospects (EC, 2015c). This confirms experiences in other countries that skills gained in public works scheme jobs are usually not relevant for private sector jobs. Participation can even lower the probability of finding employment after the programmes have ended, reflecting lock-in effects that prevents enrolees from job search or training 
activities (Card et al., 2015; Duel et al., 2010). This is a particular risk in Hungary, where high regional differences and low mobility can create a lock-in effect of public work participants in less economically developed regions. The programmes are likely to limit labour market adjustment and exacerbate already high regional differences (OECD, 2014a). In order to improve the access to the primary labour market, the government has introduced several measures including -cash 'bonus' for former public work participants who find a job in the private sector and wage subsidies for employers who hire former public workers.

Training measures can significantly improve skills of participant's and employability (Card et al., 2015). The positive effects of training are especially pronounced for young participants, for which training measures are more effective than any other ALMP programmes (EC, 2015c). However, the overall share of participants in training in Hungary is less than 10\% of all ALMP participants. Training programmes are facilitated by two institutions - public employment services (PES) that provides training for the unemployed through mostly private providers and by the public Turr Istvan Institute that provides training for public work participants. The latter focuses on training to improve agricultural, basic and professional skills.

Figure 12. Labour market status 6 months after participating in public work schemes

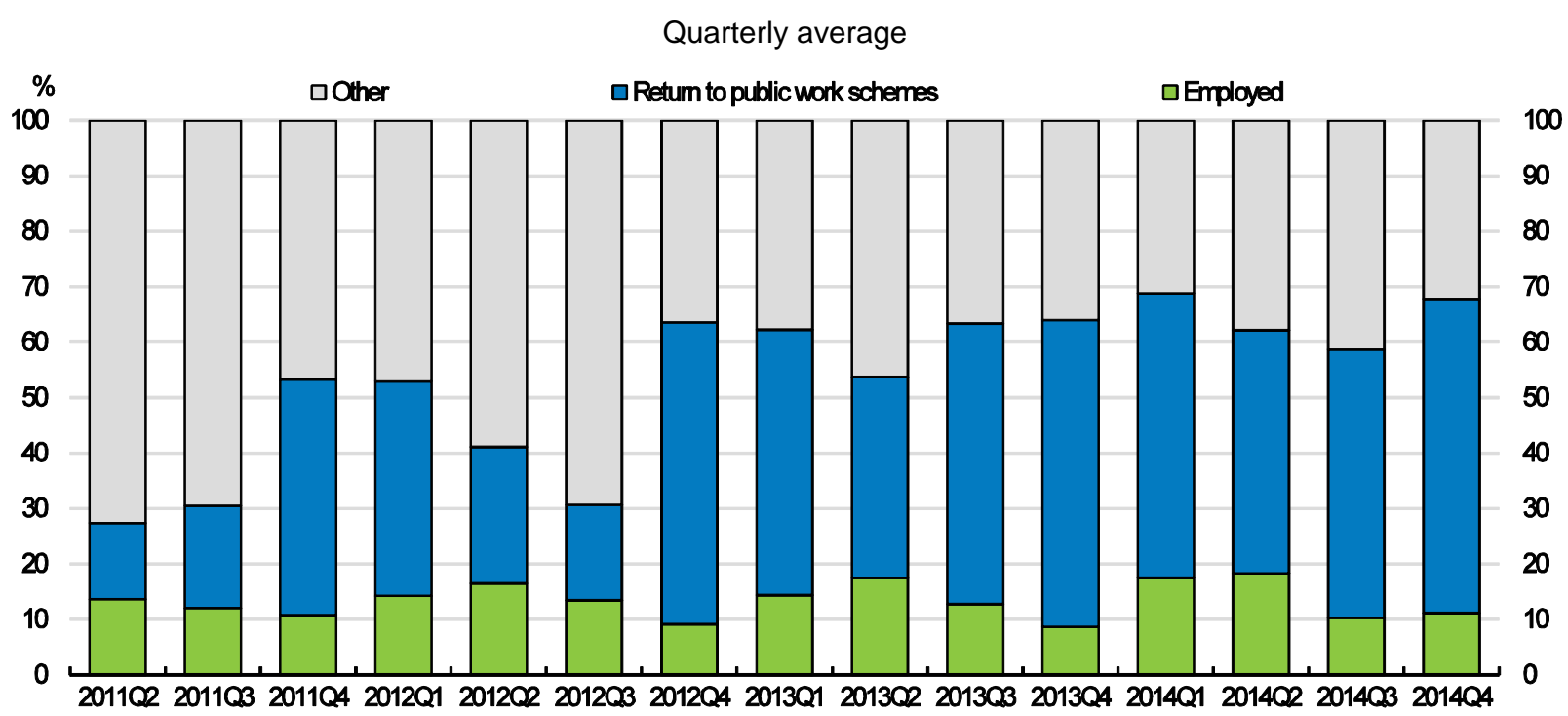

Source: Fazekas, Varga, Bakó and Molnár (2015), The Hungarian Labour Market 2015.

One way forward is the greater use of profiling to determine which unemployed should enter the public works scheme or which training should be applied according to the needs of the unemployed. Public works programmes should not be offered to early school leavers and young unemployed as these groups essentially need to acquire skills that would be transferable to private sector jobs. The share of participants with higher-secondary and tertiary education and of youth aged below 25 continues to be high, around $20 \%$ and $16 \%$. The public works scheme should be used only for the long term unemployed with low skills. For other groups, training and job search programmes are likely to be more effective. The Government has launched a new profiling system in 2016, including services based on the risk categories of jobseekers. In order to effectively implement these measures, the profiling system needs to be complemented by comprehensive evaluation of particular measures in order to effectively match unemployed to specific programmes. If such measures were successful, the public works schemes could be scaled back as over time fewer people would need this sort of support. 
In addition, a follow up program should be put in place for participants in the public works scheme. Making the existing individual action plan mandatory and offering complex programmes based on mix of training, counselling and mentoring programmes should be an important element of an upskilling strategy for the unemployed. It is important that all clients reaching 12 months of unemployment are re-profiled and should be assigned to a personal counsellor (EC, 2015c). The existing individual action plan is voluntary and limited to staff in the public employment service, leaving little room for individualised assistance. Following the recommendation from the 2014 Economic Survey of Hungary, the capacity of the public employment service should be scaled up in terms of staffing and efficiency.

\section{Securing skilled labour supply in the future}

Supply of skilled labour is further decreasing through emigration. Since 2008 emigration has increased significantly from low levels, notably to Germany, Austria and the United Kingdom (Figure 13, Panel B). Emigration is dominated by young and skilled workers (Bodnar and Szabo, 2014): surveys suggest that almost half of the Hungarians under the age of 25 are willing to emigrate. These developments have contributed to labour shortages, most pronounced in the health care sector. For example, since 2012 the number of experienced Hungarian doctors working in Germany has increased by more than $30 \%$ (Figure 13, Panel A). Experienced and qualified doctors aged 30-39 are the most likely to leave (Girasek et al., 2013). The high number of official doctor qualification certificates issued to doctors wanting to work abroad also indicates skill erosion in the health sector. The dominant push factors in emigration are relatively low salaries, poor working conditions and limited research opportunities.

Attracting emigrants to return to Hungary can boost the supply of skilled labour as evidence suggests that return migrants bring back skills and knowledge, spurring innovation and growth (OECD, 2008). However, according to surveys only $10 \%$ of recent emigrants intend to return in the near future (SEEMIG, 2014). The government is addressing this issue through the recently launched 'Come Home, Youth!' program with a budget of HUF 100 million, mainly targeting skilled youth. The program covers part of the resettlement costs and provides additional monthly wage subsidy (EUR 320) for the year following the repatriation. As the program has attracted only few return emigrants so far, other steps are necessary to attract high skilled workers to return from other countries.

As a member of the European Economic Area (EEA), the scope for attracting skilled immigrants is restricted to facilitate access for workers outside the EEA. These workers need to obtain a working permit that can be granted only if the employer can prove that no Hungarian job seeker is suitable for that job (OECD, 2014a). Many OECD countries are using a more supply driven system, whereby potential migrants are chosen according to awarded points, which reflect qualifications, skills, language proficiency and experience allowing selected immigrants to enter the country without a job offer to search for employment. However, impact of this measure can be limited in Hungary, where language is so important for labour market success. The existing EU Blue Card system, which grants special residency rights and work permits to highly-skilled migrants outside of Europe, led to only four permits issued in the last years. Hungary could grant special tax treatment for highly-skilled immigrants. Several countries offer tax concessions to specific groups of highly skilled workers: in Belgium, the state grants a $75 \%$ exemption from wage withholding taxation to temporary and permanent foreign workers while Italy offers a $90 \%$ of exemption from personal income tax earned for three years. In Hungary, a possible approach could be to focus on reducing social security contributions, which is one of the highest in the OECD countries.

One group of readily available high-skilled immigrants is international students. They are particularly attractive as they have studied in Hungary and are thus familiar with the language, institutions, and culture. The government is trying to boost the relatively low number of foreign students with a scholarship program through a series of bilateral agreements, mainly from outside Europe. This should be supplemented with measures to retain foreign graduates. Many countries allow university students to look for job after completion of their studies. For example, Sweden allows students to work during their studies. 
Hungary has no special provisions for staying on, and graduates must use the existing labour migration channels if they are to find qualifying employment (OECD, 2014b). Therefore, it is important to ease conditions for international graduates' work permits by allowing them to look for a job after graduation. In addition, a post-study work experience visa should afford a transition pathway from temporary to permanent residence.

Figure 13. Emigration is low, but has been increasing significantly over recent years

A. Changes in the numbers of doctors trained in Hungary in 3 OECD countries', 2000-2012

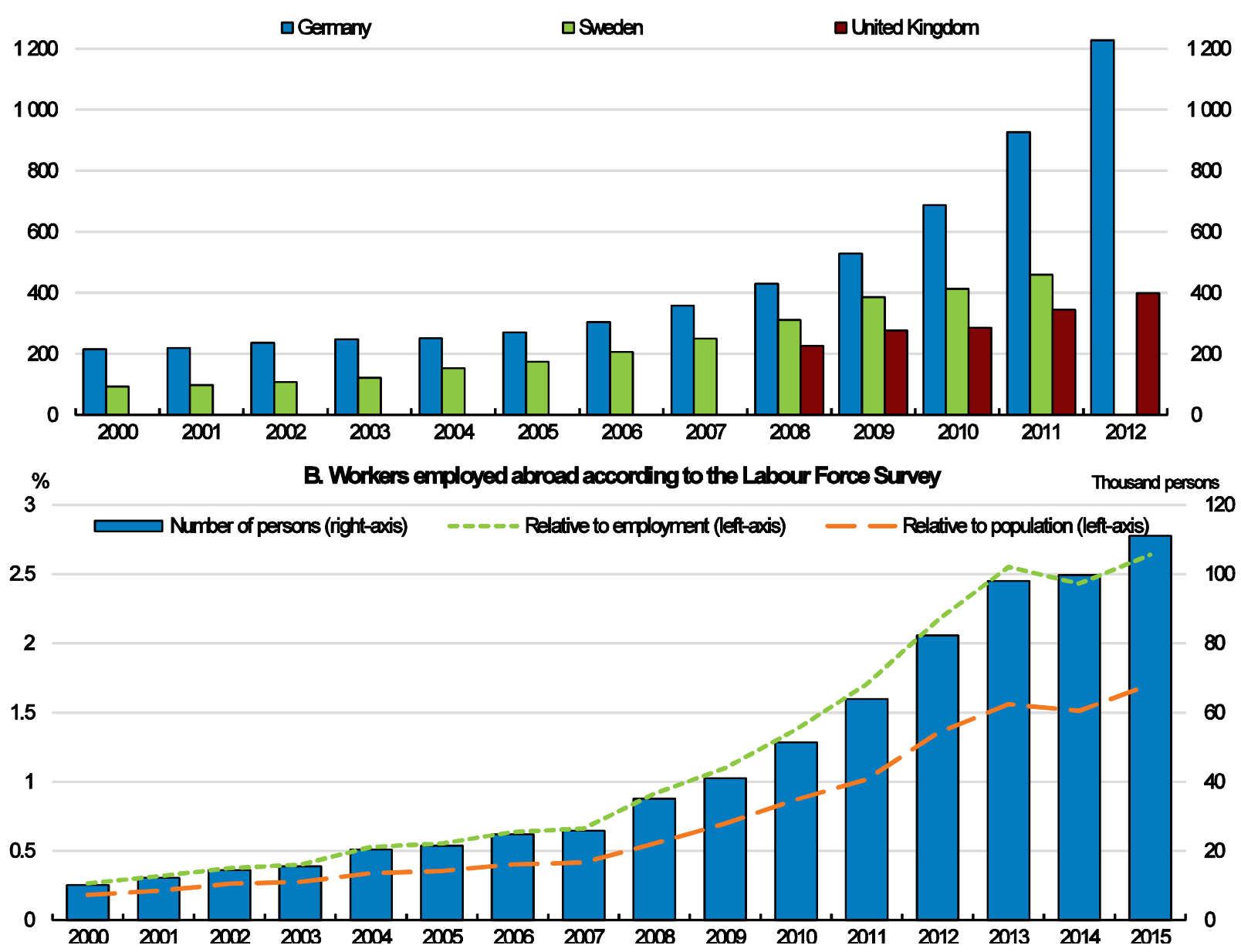

1. Data for Germany refer to the number of doctors of Hungarian nationality. Data for Sweden are only available up to 2011 and data for the United Kingdom are only available for 2008-2012.

Source: OECD (2015), International Migration Outlook 2015, Figure 30; Magyar Nemzeti Bank (2014), Growth Report November 2014, Figure 2.32; Hungarian Central Statistical Office (2016), Labour Force Survey.

\section{Securing future skills formation that meet the labour market needs}

The education system is essential in developing relevant skills. A constantly changing economic environment poses challenges in this respect, as it requires more endogenous adjustment to better align student learning outcomes with changes in labour market demand. However, low youth employment rates suggest that little progress has been achieved. Furthermore, citizen satisfaction with the education system is lower than in neighbouring countries and below the OECD average (OECD, 2015b). In addition, public spending on education has been decreasing, leading to internationally low spending per student, particularly for primary and secondary students. 
Learning outcomes for 15 year-old students are worse compared to the OECD average in all assessed subjects and in mathematics and science have been deteriorating over time (OECD, 2015b; Figure 14, Panel A). Also, students are not sufficiently prepared to perform tasks required in today's labour market such as solving non-routine problems in unfamiliar situations. Indeed, PISA tests show that problem solving skills are amongst the weakest in the OECD. Particularly, students perform significantly worse in problem solving than students in other countries with similar performance in core subjects, reflecting that prevailing Hungarian teaching practises remaining content-centred with little space for knowledge application (Figure 14, Panel B). Such differences are likely to reflect that teaching content gives little space for knowledge application. In contrast, today's changes in economy and in technology require the ability to adapt to new circumstances and learning in unfamiliar contexts. Surveys of adults' skills show that those who reach the highest level of proficiency in problem solving are also those who have access to jobs in the occupations with the strongest employment creation (OECD, 2014c). As a result, 15 year-olds who lack advanced problem solving skills are faced with higher labour market risks and potential economic disadvantage as adults.

Figure 14. Student performance in PISA 2012 has deteriorated

\section{A. Student performance in mathematics in PISA 2012}

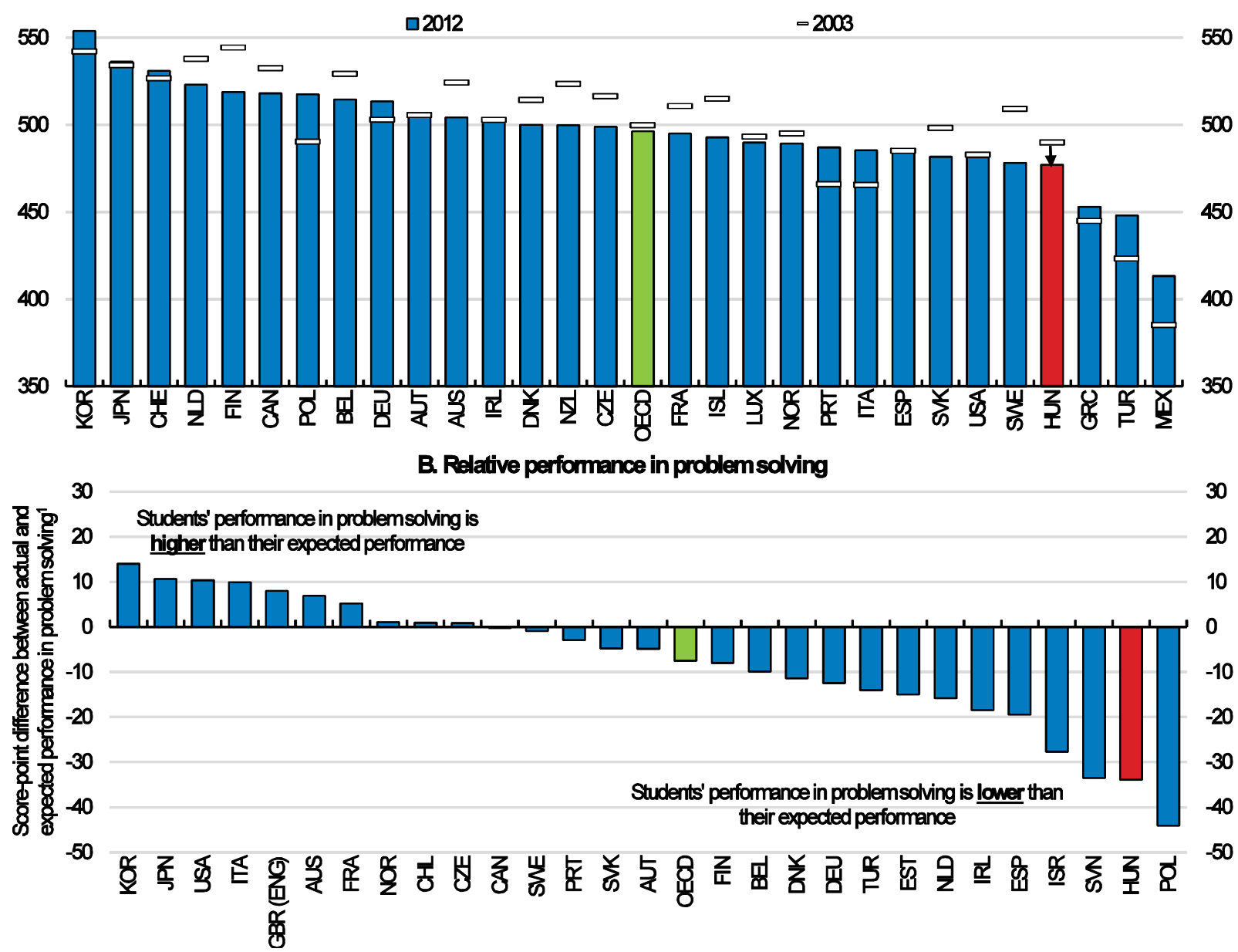

1. Each student's expected performance is estimated, using a regression model, as the predicted performance in problem solving given his or her score in mathematics, reading and science.

Source: OECD (2014), PISA 2012 Database, Table I.2.3b and V.2.6. 


\section{Enhancing the quality of learning and strengthening skills valued in the labour market}

The introduction of new, modern teaching methods and a new curriculum require highly qualified and motivated teachers (OECD, 2005b; Chetty et al., 2011). However, the conditions for teachers remain unattractive with some of the lowest salaries in the OECD, equivalent to half of average tertiary graduate earnings (Figure 15). Moreover, low wages are encouraging the best teachers to find employment elsewhere. Indeed, former teachers who are now employed in other areas of the economy have higher average earnings than those of current teachers (Varga, 2014). In addition, many teachers take on second jobs to supplement their earnings (EC, 2013), which together with relatively high administrative burdens can negatively affect preparation and the quality of their teaching.

Figure 15. Teachers are amongst the lowest paid in the OECD

Ratio of salary using annual average salaries (including bonuses and allowances) of teachers in public institutions relative to the wages of workers aged 25-64 with similar educational attainment, 2013

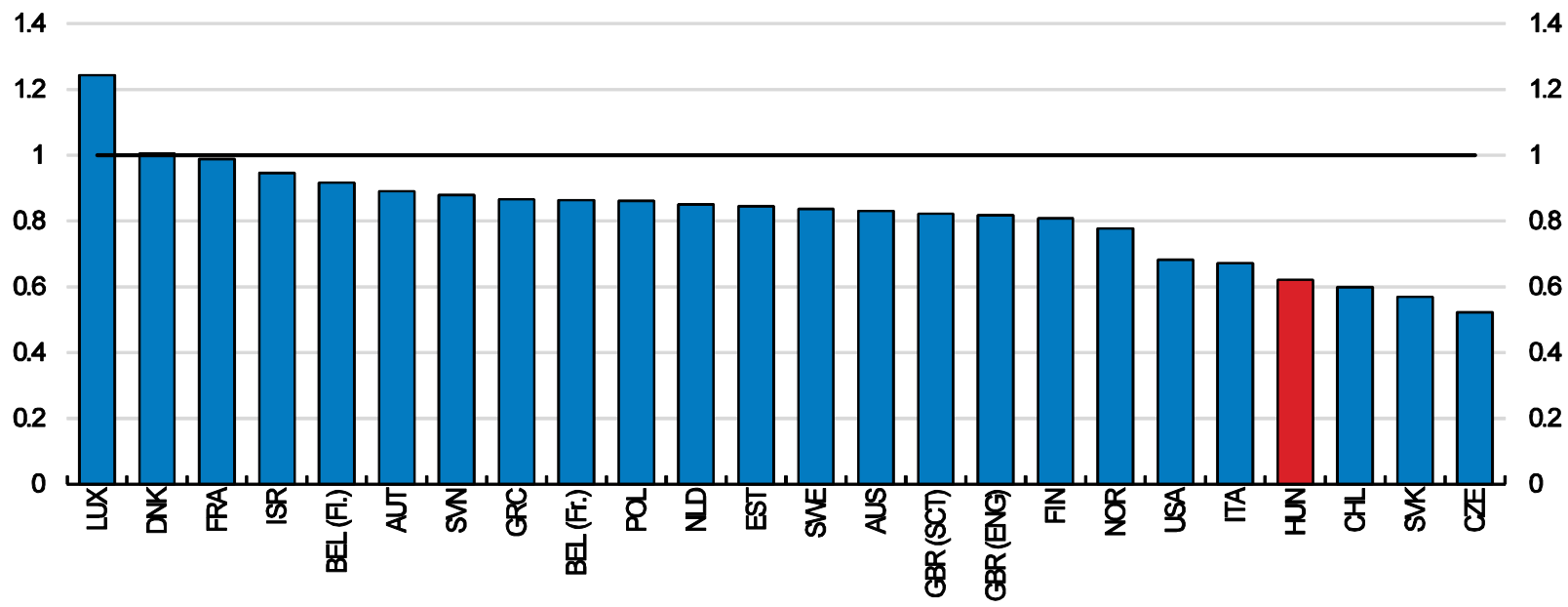

Source: OECD (2015), Education at a Glance 2015, Table D3.2a.

The government introduced a new career model and promotion system for teachers to improve conditions and to ensure better quality of teaching. This is a step in the right direction as it is boosting teachers' wages. However, for some teachers, this increase is effectively cancelled out by their restructured workload and the removal of salary supplements (EC, 2014). The last significant wage increase in 2002 helped retain many young teachers in education, but the effect disappeared as the relative earning of young teachers began to deteriorate again thereafter (Varga, 2014). Therefore, the implementation of a new career model path should ensure effective wage increases, especially for the new teachers to make the profession more attractive. In addition, in countries where teachers have relatively low pay, an element of performance-based pay can improve student performance (OECD, 2012b). Recent reforms in Hungary have centralised responsibilities for schools teachers' salaries and career system. In this context, the authorities should restore should ensure that organisational and some pedagogical autonomy remains with schools, including the management of human resources (OECD, 2014a).

Another problem is the administrative burden, which almost $30 \%$ of Hungarian teachers find excessive (much higher than the EU average) and identify as the biggest hindrance for the teaching profession (EC, 2013). Freeing up teacher resources by reducing administrative burdens would give teachers more time to teach and to prepare and enable principals to engage more in pedagogical leadership. Measures to identify and decrease unnecessary administrative burden of teachers need to be implemented. An example to follow could be the online workload challenge introduced in the UK, which aims to identify unproductive and unnecessary workload through responses from teachers (UK, 2015). 
The curriculum also needs to be updated to better reflect changing demands in the labour market. For example, the demand for more generic ICT skills are increasing across all professions, raising the need for additional ICT qualifications. Hungarian employers identified computer skills as one of the most important elements when recruiting graduates (Eurobarometer, 2010) and computer skills remain relatively weak (Figure 16, Panel A). Therefore, basic ICT skills should be adequately taught and strengthened in primary and secondary school. The use of ICT in classes in Hungary is among the lowest in the EU countries, reflecting a lack of appropriate qualifications, motivation and teacher support (Public education strategy, 2014). ICT training should take up a more horizontal form of knowledge application across all subjects in the curriculum to correspond with ICT usage in the economy.

Other important skill requirements in an increasingly internationalised economy are language capabilities, which employers place particular emphasis upon (Eurobarometer, 2010). However, in Hungary only $6 \%$ of students in primary education learn more than one foreign language, the lowest level in the EU, and the number of foreign languages learnt in secondary school is below the EU average (EC, 2015d) leading to weak foreign language ability among population (Figure 16, Panel B). The number of foreign language lessons should increase and external assessment of student's language proficiency should be used to identify bottlenecks in the learning process.

Figure 16. Computer skills and language proficiency are weak

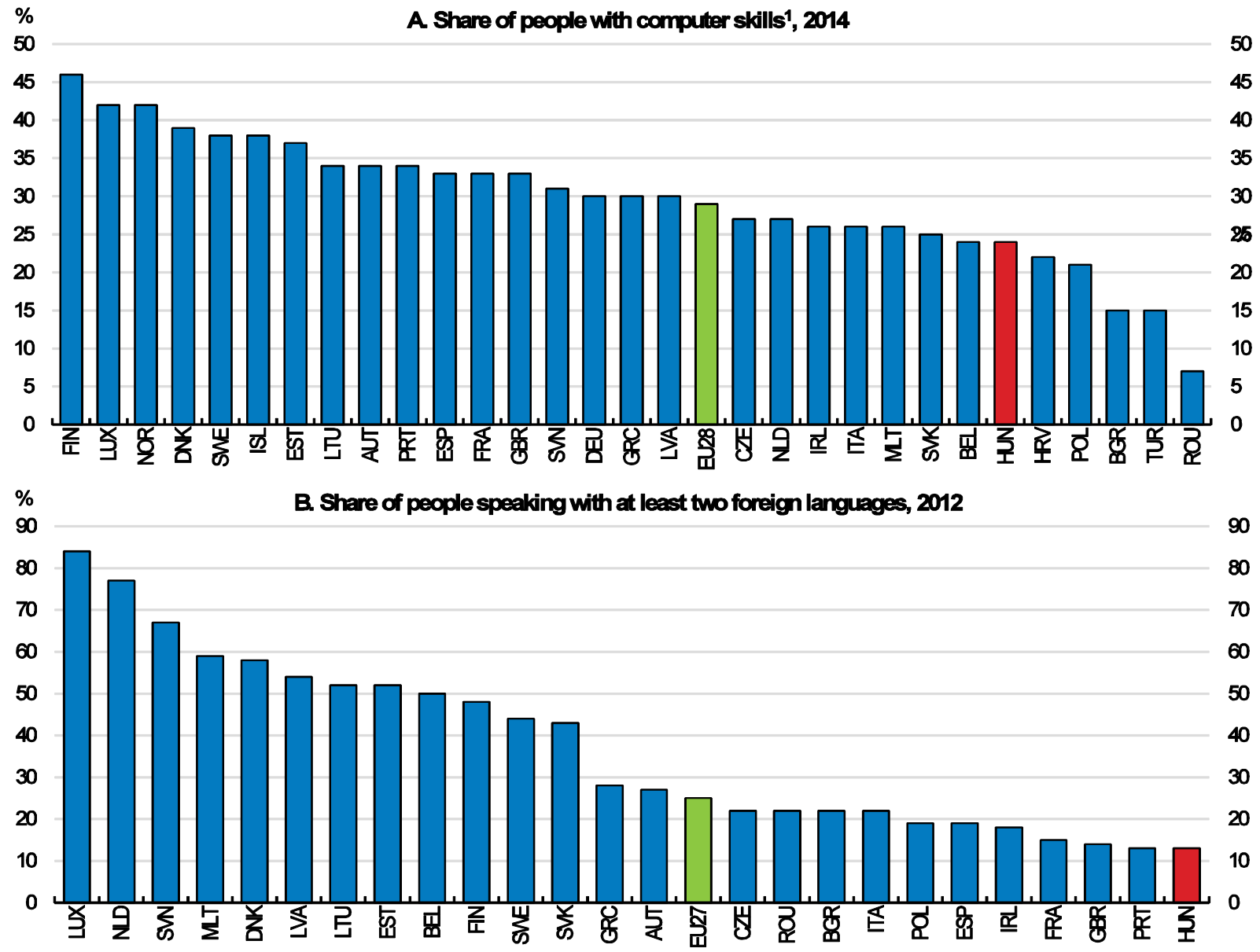

1. Share of individuals aged 16 to 74 reporting to have carried out five or six specific tasks related to computer use.

Source: Eurostat (2015), Individuals' level of computer skills; European Commission (2012), Special Eurobarometer 386: Europeans and their languages. 


\section{Selectivity in education is hampering the basis for skills formation}

Early tracking and streaming in the education system creates strong socio-economic dependencies, hampering the skills formation of disadvantaged groups, and complicating their integration into the labour market (Box 3). Enrolment in lower tracks of secondary school has a detrimental effect on skills (Herman, 2013). Analyses of the PISA results show that the education performance gaps with regard to the socioeconomic background of students is larger in Hungary than the OECD average and the variation across schools is higher than within the individual schools (OECD, 2013a). The implication that the education system tries to meet the needs of each student by creating different education tracks rather than providing general comprehensive education to reduce effects stemming from different socioeconomic backgrounds.

\section{Box 3 Early tracking in the education system}

Education is compulsory until the age of 16 and characterized by early tracking. The first tracking can take place at age 10 or 12 , where students can be admitted into a longer general education path -8 or 6 year gymnasium (The share of students in 5-8 grades gymnasium was $6.6 \%$ in 2014/2015). The next tracking stage occurs at age 14 , when students can choose between three secondary institutions: gymnasium - a four year general secondary school; four year vocational secondary school, which provides a mix of general content with vocational education; and three year basic vocational school. The two four year programmes end with a school leaving exam - matura - that provides direct access to tertiary education. The three year vocational schools prepare students for the labour market, although the graduates can take an additional two years of schooling to get the matura exam. Selection into these tracks is based on school grades and entrance examination. The students are roughly equally distributed across the secondary institutions.

PISA test results point to a large variation between schools and certain population groups, such as the large Roma minority (7.5\% of the population), tend to be left behind. Four out of five adult Roma have only primary education, reflecting low preschool enrolment, which harms their school readiness and thus their chances to achieve better education and obtaining necessary skills needed for labour market entry later in life (WB, 2016). Early tracking only exacerbates the initial differences. The relative educational attainments of Roma have improved over the last decade; nonetheless the drop-out rate remains above 50\% (Figure 17).

Figure 17. School enrolment and graduation rates of minority groups remain poor in Hungary

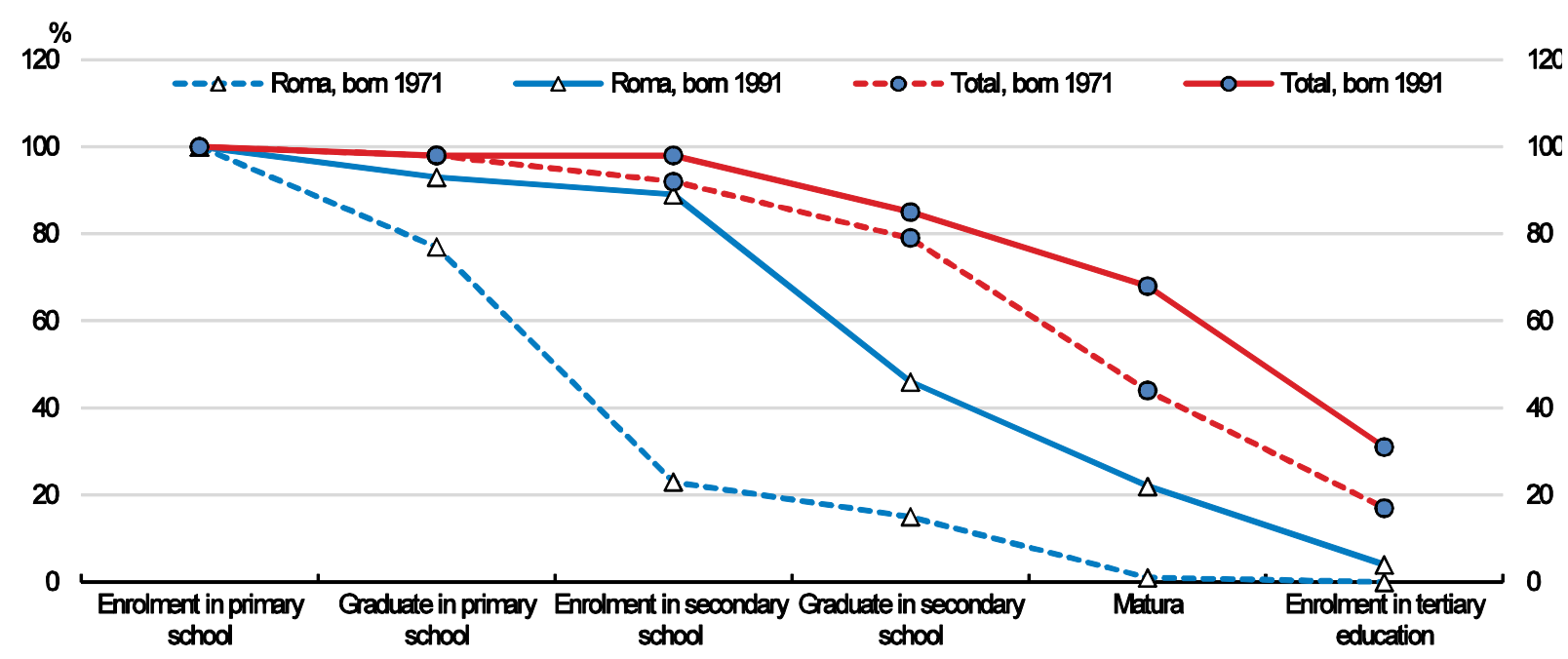

Source: EC/World Bank/UNDP Survey 2011. 
If the education system could reduce initial differences stemming from different socio-economic backgrounds, average skills acquisition would increase. This would reduce the incidence of long-term unemployment and non-active in the working age population. The government is trying to limit the influence of socio-economic backgrounds by making early childhood education compulsory from age three, reflecting international research that indicates that children who attend pre-primary education have better school outcomes (OECD, 2013b). Further steps are necessary to mitigate the initial inequalities. The system of early tracking in education should be either abolished or more flexibly allow movement across tracks. In addition, extending the period of compulsory grammar school by one more year should be considered. In countries where students attend comprehensive school until a late age, inequalities of student outcomes are lessened, and overall performance is improved (Herman et al., 2011)

A new set of teaching tools focusing on disadvantaged students should be implemented in the educational system. Additional compensation and training of teachers needs to be provided in the areas and regions with a prevailing share of disadvantaged students. The government has already put in place special allowance to teachers who work in towns and villages classified as beneficiary municipalities regarding their depriving socio-economic and infrastructural situation and regions with high unemployment. Early detection mechanisms, such as periodic individualised assessments of students by several groups of teachers, allow educators to identify struggling students and offer them the necessary support early on, before falling behind the pace of their peers. A new set of inclusive teaching methods to equip teachers with a new curricula and training to support skills development in classes of diverse social background should be implemented. The impact assessment of one of the pilot programmes used between 2003 and 2006 found that the performance of pupils taught according to this inclusive methodology improved student outcomes already in the short run compared to outcomes of students in non-participating schools (BI, 2010).

\section{Vocational training provides narrow labour market skills}

Vocational education and training (VET) is provided through vocational training schools and vocational secondary schools. Vocational training schools provide limited general education content and focus on providing practical workplace training. In contrast, vocational secondary school combine general and vocational education and students may seek entry directly into tertiary education.

Vocational training is supposed to prepare students for direct access to the labour market, but its quality has deteriorated. Over the years, vocational training has become the most likely education path for children with uneducated and poor parents (Keller and Mártonfi, 2009). This strong socio-economic selection bias is strengthening the perception of poor quality in vocational training. Indeed, a relatively high share of survey respondents considered vocational training to provide poor quality education (Figure 18). This impression is confirmed by empirical studies showing that students with comparable results in primary school tend to advance at a slower pace in mathematics and reading in vocational training programmes than in general secondary schools (Hajdu et al., 2015). Moreover, the difference in solving complex problems between students in vocational training programmes and their peers in general secondary schools is one of the largest in the OECD. In addition, the drop-out rate of $30 \%$ in vocational school is much higher than in other schools (Martonfi, 2014). 
Figure 18. Vocational schools are perceived to be of low quality

Perceived vocational education and training image and quality

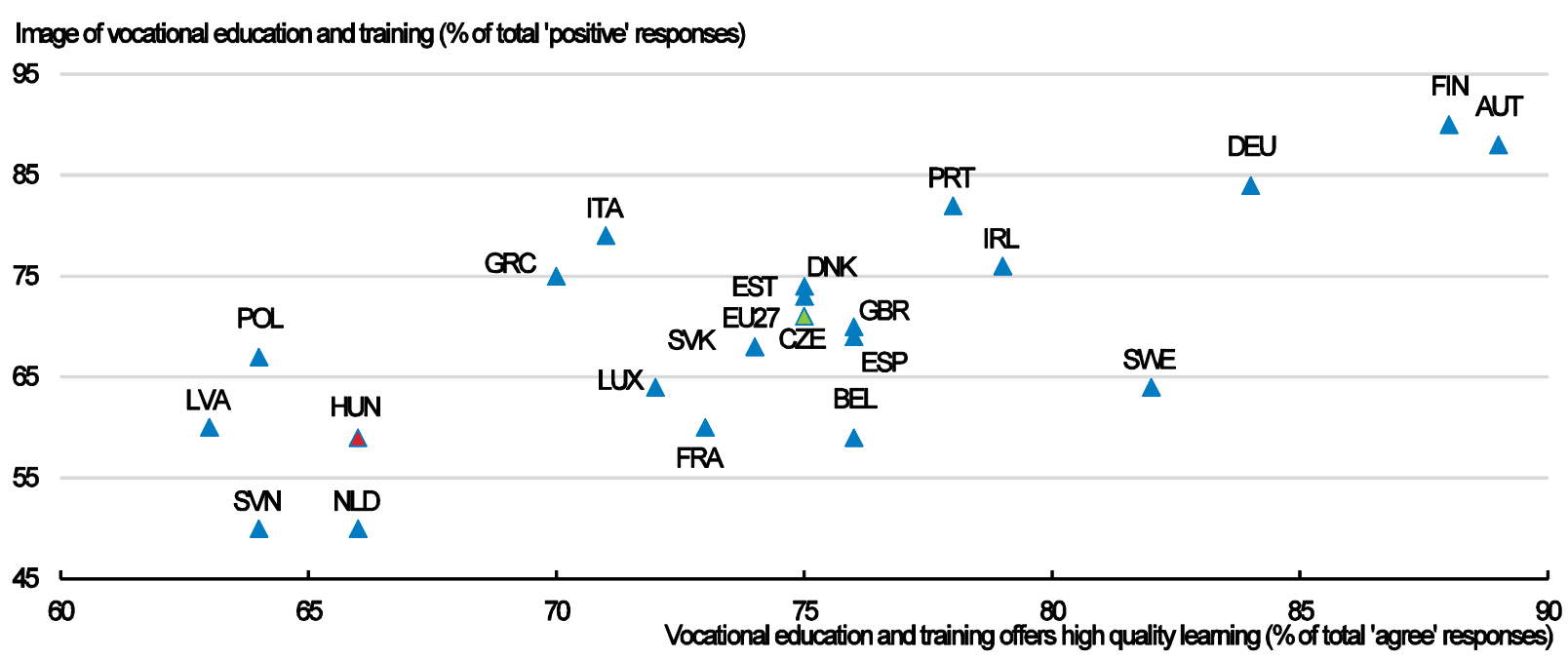

Source: European Commission (2011), Special Eurobarometer 369, "Attitudes towards vocational education and training", Report, September 2011.

As a result, labour market outcomes of vocational training graduates are characterised by high unemployment rates, greater difficulties in finding a first job, and wages that are $25 \%$ lower than other secondary school graduates (Figure 19; Hajdu et al., 2015). Moreover, graduates work relatively often in occupations that are different from their field of study. An additional concern is that wage dispersion tends to increase over time, suggesting that VET graduates are less likely to adapt to changes in a labour market.

Weak emphasis on general skills in vocational training can weaken employability prospects of the graduates in the long term. The current number of lessons for general skills acquisition is already much lower than in the dual learning system of vocational training in Germany (Hajdu et al., 2015). Although, language lessons have added to the vocational training curricula, teaching general skills has shortened with the 2013 reform. Class time dedicated to mathematics was cut by half and ICT subjects have been eliminated (Martonfi, 2014). The rapid changes in technology and the structures of the economy suggest that the labour market would favour those with more general skills and those more likely to adapt. Empirical research shows that beside work place experience, better language skills and a capacity for acquiring new knowledge are essential for successful labour market integration (MKIK 2014). Vocational programmes need to give sufficient weight to general academic, numeracy and literacy skills to reflect the labour market developments (OECD 2010). Students should be systematically assessed at the point of entry to vocational programmes to ensure a basic minimum of skills and identify those in need of targeted support.

The government is reforming VET training (Box 4) by introducing the possibility to extend the studies by two years. The effectiveness of this measure might be undermined by the prevalent high dropout rates and the fact that VET students are already lagging behind in general academic, numeracy and literally skills. Without increasing the basic skills content of the current 3-year curriculum, students may have difficulties to acquire the level of key competences necessary for mastering subjects usually required for the upper secondary school-leaving exam (EC, 2015d). Therefore, merging vocational training schools with vocational secondary schools with more general content could emphasise the value of general skills and improve the reputation of vocational training, helping to close the gap in labour market outcomes between vocational training schools and vocational secondary schools. 
Figure 19. Labour market outcomes of vocational school graduates are unsatisfactory

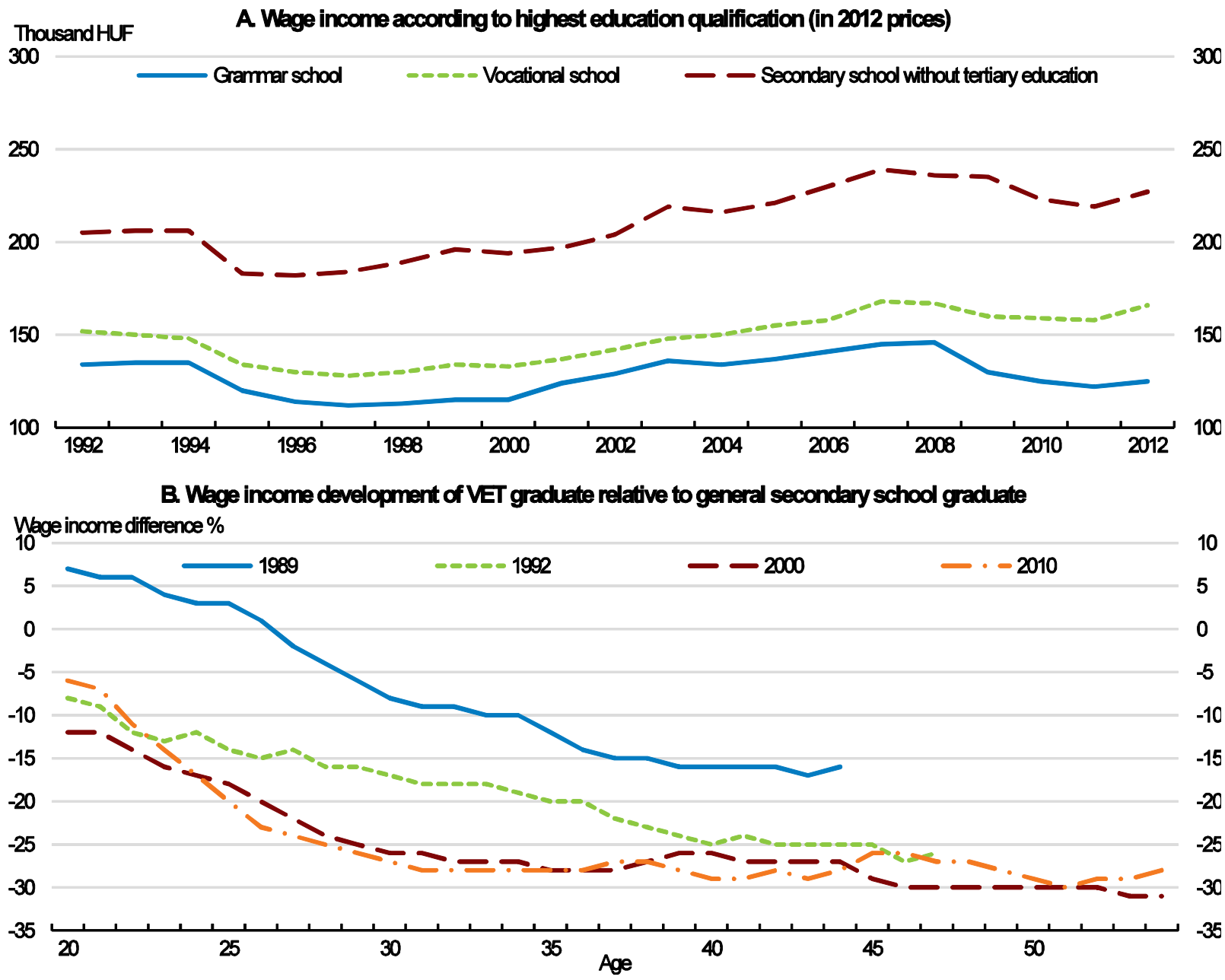

Source: Hajdu et al. (2015), NMH Bértarifa-felvételei: http://adatbank.krtk.mta.hu; Kezdi G. (2014), Zsákutca a magyar szakmunkásképzés, De Facto.

\section{Box 4 Changes in the secondary education system}

The new changes in vocational education aim to attract more students to vocational education. These measures should take effects between 2015 and 2016,

- The name of secondary vocational schools will be modified to "vocational grammar school" in order to attract more students to VET. In order to take a secondary school leaving certificate and a vocational qualification at the same time, the share of vocational training is planned to be higher.

- The path from vocational training to secondary school leaving certificate will be eased. After getting the vocational qualification at the end of the third year, vocational training graduates, unless they request to terminate their legal status as students, automatically continue their studies for two more years to obtain the secondary school leaving certification. 
The government is implementing reforms to increase the emphasis on workplace training. More than half of students from vocational institutions are participating in workplace training, the third highest rate in the EU (EC, 2015). The government wants to increase this to $70 \%$ by 2018 through additional financial incentives for companies. The problem, however, is that high participation in workplace training is not improving the labour market outcomes for VET graduates. Empirical research shows that apprenticeship students have better chances of finding a job, but there is no wage difference between apprentice and nonapprentice graduates, suggesting that no specific skills have been acquired during apprenticeship (Horn, 2013). The government should carefully monitor and assess the results of the recent reforms.

The benefits of workplace learning can be ensured by tighten up the required quality standards. Quality standards can be enforced through inspections and effective assessment of the skills acquired through training. In Germany and Denmark there is strong quality control and firms need to meet quality standards to be licensed to take on apprentices while the quality of training is monitored throughout the apprenticeship (OECD, 2010). Implementing similar practices in Hungary should help to avoid the allocation of students to unskilled tasks and to prevent training being narrowly focused on firm-specific skills. Contractual arrangements should define obligations of trainee and employer in order to achieve learning objectives, which should be developed with the involvement of employers and schools.

\section{Tertiary education must be more responsive to the labour market needs}

Tertiary graduates enjoy favourable labour market prospects in terms of wages and employment. However, in terms of skills two major problems remain unresolved: (i) the supply of tertiary graduates in economy is still persistently low, and (ii) the quality of the tertiary education outcomes in terms of labour market prospects is uneven.

The supply of tertiary graduates is severely impaired by low completion rates and long completion times (Tremblay et al., 2012). Less than half of all students are able to finish studies within the required time (OECD, 2013b). OECD estimates suggest that graduation rates can increase up to the OECD average by improving completion rates to the level of the best performing countries (Figure 20). Non completion and late completion of degrees are attributed to various factors such as insufficient academic preparation prior to enrolment, and slow study progression. This is much more pronounced in ICT education, where only just $31 \%$ finished their studies within the required time. A high proportion of students in Hungary drop out either by not being able to undertake payment of tuition fee or opt out at reclassification from state-financed to fee-paying places due to weak academic achievement.

In general, there is a strong demand for tertiary graduates. However, there is great variance among labour market outcomes of different tertiary graduates. For example, graduates with degrees in informatics and engineering earn more than twice as much as graduates in social science or agriculture (Figure 21). Moreover, one in four graduates in tertiary education works in a job that does not require a tertiary degree (Nyusti and Veroszta, 2013). Over-qualifications are strongest in the fields of social science, agriculture and humanities. Graduates who have identified themselves as overqualified have on average $20 \%$ lower wages than the better matched graduates (Varga, 2013). These over-qualifications entail a potential waste and misallocation of scarce public funds spent on tertiary education. 
Figure 20. Graduation rates can be significantly increased through raising completion rates

Estimated graduation gains from raising completion rates to best international level ${ }^{1}$

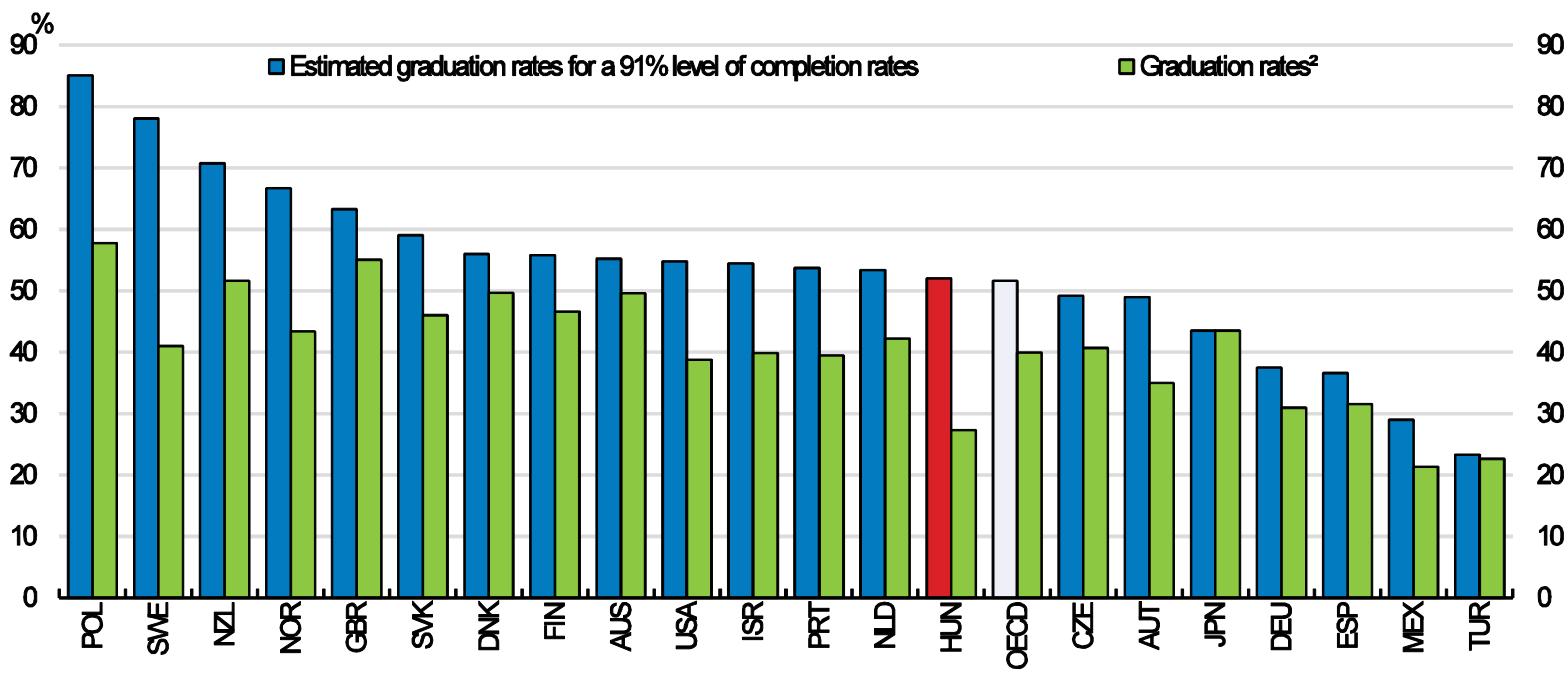

1. Estimations based on a $91 \%$ level (Japan) of completion rates at tertiary-type A level of education, considering that the level of entry rates remain constant. Latest available data are for year 2011.

2. Tertiary-type A programmes (first-time graduates) graduation rates, which represent the estimated percentage of an age cohort that is expected to graduate over their lifetime.

Source: OECD calculations based on OECD (2013), Education at a Glance 2013, Table A3.1a and A4.1.

Figure 21. Difference in income and labour market outcomes by field of education

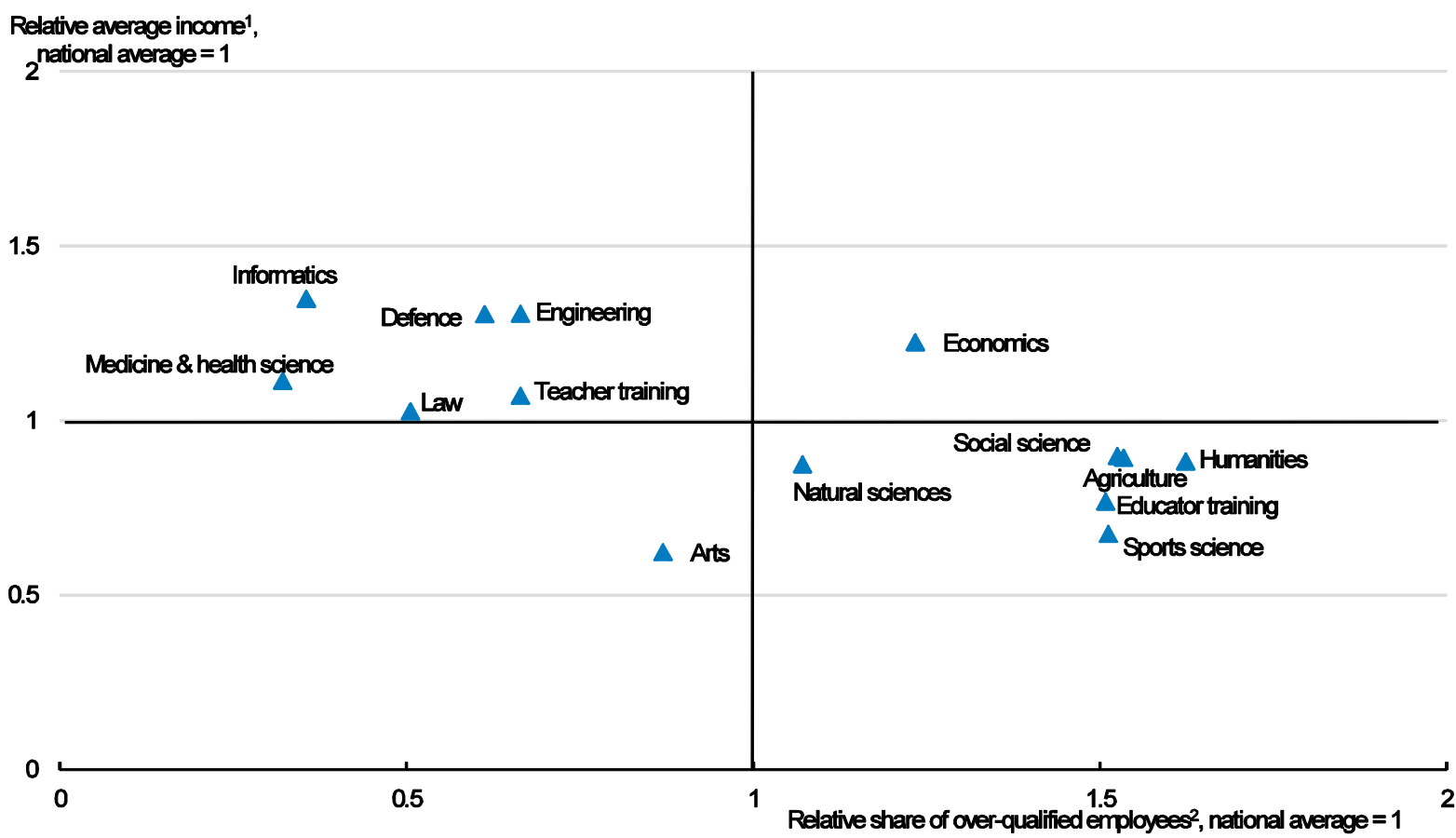

1. Recent graduates' average gross total income per month.

2. Share of employees working in jobs that do not require higher education qualifications.

Source: Educatio Public Services Non-profit LLC. (2014), Hungarian Graduate Career Tracking 2013, Figure 61 and 66. 
One way forward to reduce dropout rates and increase participation in the tertiary education is to expand means-tested support for disadvantaged students. Recently, around $30 \%$ of students pay tuition fees, while the rest are admitted in state-financed places. These state funded places are set according to the score-limits mainly based on high school results and Matura exams, which make the admission system regressive. Coming from a stronger secondary school will increase students' chances, while those coming from less educated families and weak schools are unlikely to get admissions to prestigious universities and are likely to pay tuition fees. Therefore, means tested state grants should be expanded and provided to those students coming from disadvantaged and poorer families. OECD research suggests that student financial support systems that provide both loans with income-contingent repayments and means-tested grants promote access and equity of higher education and lead to better outcomes for weak students (OECD, 2012c). For example, Australia and New Zealand have used this approach to mitigate the impact of high tuition fees and to encourage disadvantaged students to enter higher education (OECD, 2012).

In addition, there is a room to increase the funding to tertiary education by supporting programmes with better labour market outcomes. Public returns from tertiary education in Hungary are amongst the highest levels in the OECD countries (Figure 22), providing incentives to investment in tertiary education. Increased funding mechanisms could, for example, provide differentiated rewards to specific courses that provide skills closely linked to labour market needs, such as certain subjects within the STEM disciplines. This would make the system more responsive to the changing needs in the labour market.

Figure 22. Private returns on tertiary education are high in Hungary

Internal rate of return of a person attaining tertiary education ${ }^{1}$

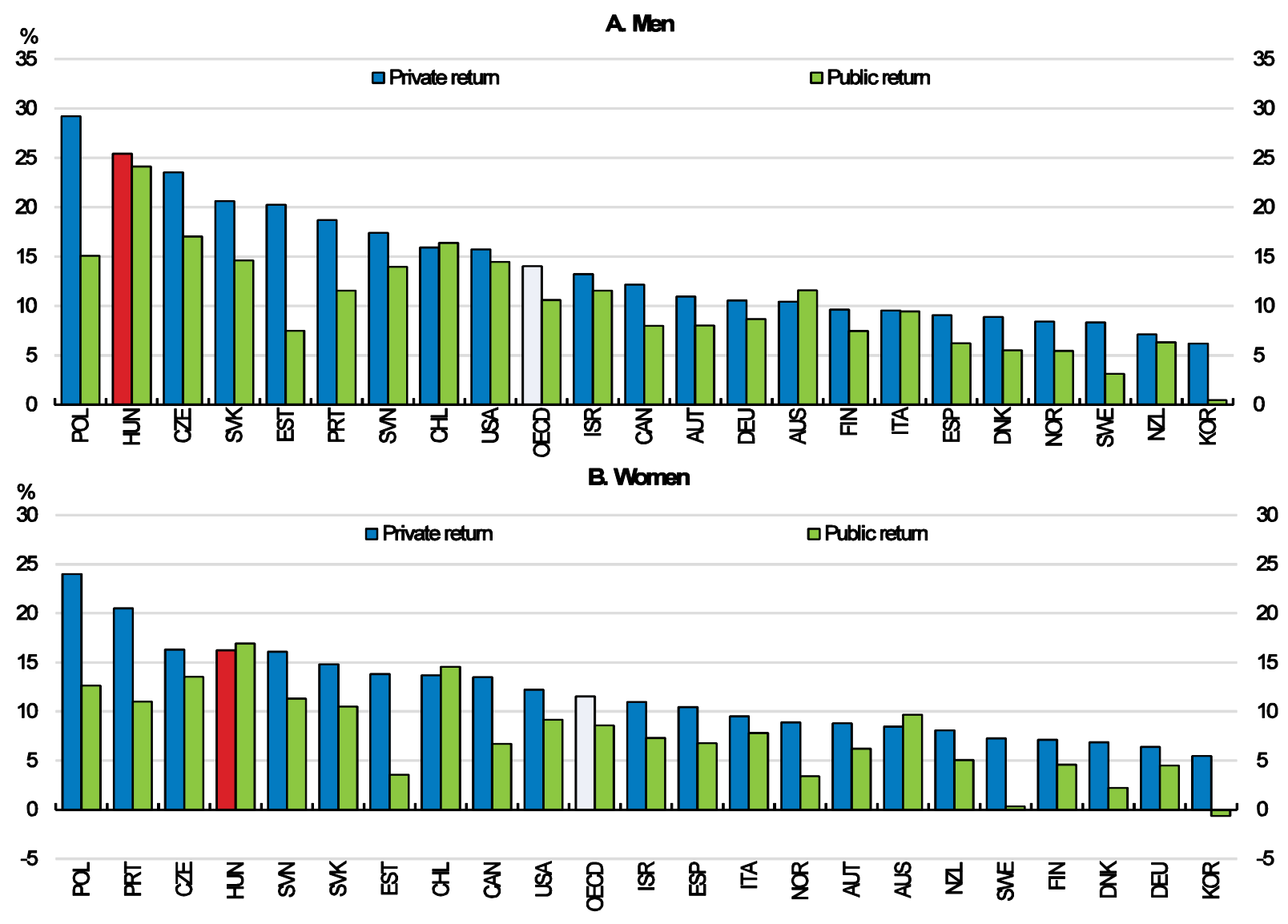

1. As compared with a person attaining upper secondary or post-secondary non-tertiary education, in equivalent USD converted using PPPs for GDP. The internal rate of return indicates at what real interest rate the investment breaks even. 2011 data.

Source: OECD (2015), Education at a Glance 2015, Table A7.3a, A7.3b, A7.4a and A7.4b. 
Responsiveness to labour market needs should be further encouraged through career counselling. Relatively few students pursue tertiary programmes in science and engineering fields compared to the rest of the OECD (Figure 23), despite better labour market prospects. The government has already increased engineering quotas for state-financed places in order to increase the enrolment rates in engineering fields. However, this has little effect thus far on improving the participation in these fields; rather the raised quotas led to smaller admission score-limits in some engineering programmes, meaning that some weak students have been admitted (Biro, 2012). More effort needs to be dedicated to providing individuals with information on market returns of various career paths. Since 2013 -based on legal authorisation- an integration of administrative datasets at the individual level was introduced and led to the improvement of career tracking. This is a welcome step, but should be strengthened by improving guidance and counselling at the secondary school level. This can help students choose a course with better labour market outcomes.

\section{Figure 23. Students are not entering fields where labour market demand is high}

New entrants to tertiary education by field of education ${ }^{1}$

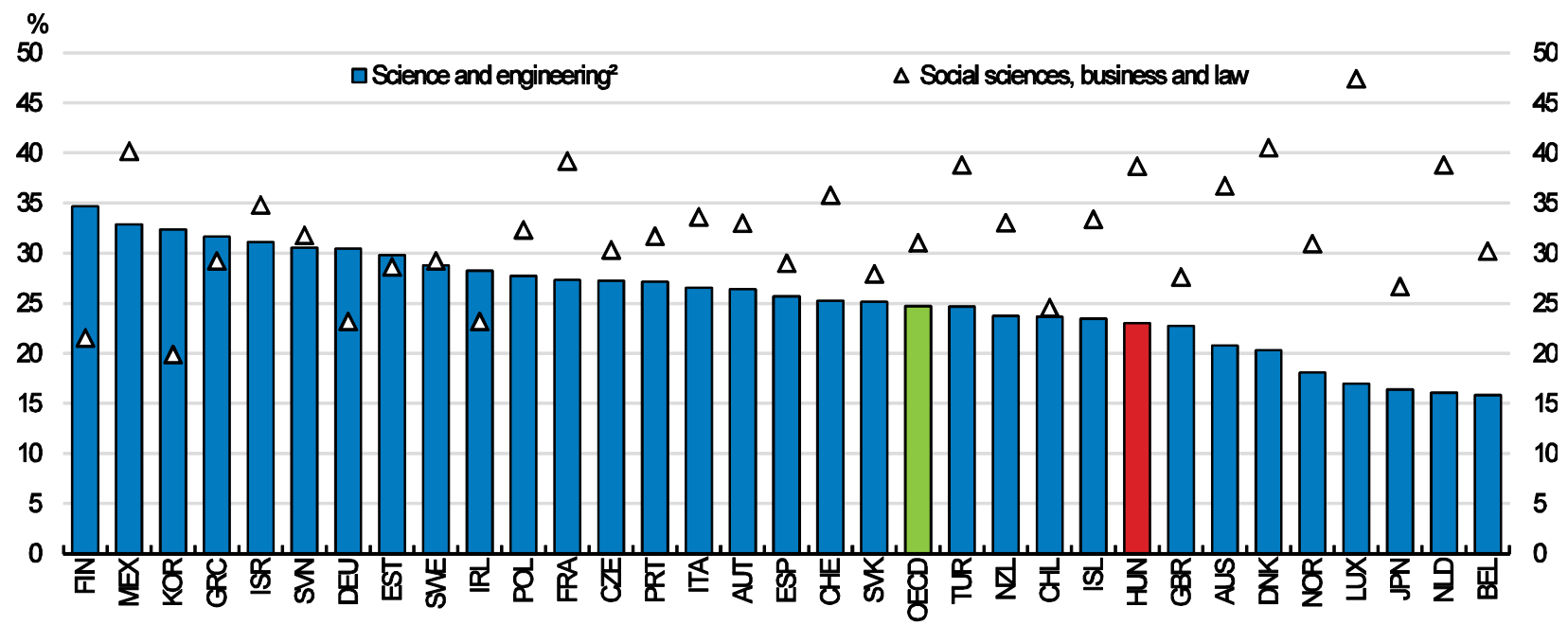

1. Latest available data are for year 2012.

2. ISCED field of education 4 and 5.

Source: OECD (2014), Education at a Glance 2014, Table C3.3a. 
ECO/WKP(2016)88

\section{Main recommendations to enhance skills}

Increasing the supply of skills by enhancing women's labour market participation

Key recommendations

- Expand early childhood care. Reduce the effective length of parental leave and provide incentives for paternity leave.

\section{Upgrading skills of older workers}

Key recommendation

- Creating a tool set, including individual learning accounts, to promote lifelong learning..

Other recommendations

- Scale up the wage subsidy program targeted at older unemployed workers and supplement it with job search assistance and job search monitoring measures.

\section{Reforming active labour market policies in order to improve skills of the unemployed}

Key recommendation

- Increase the focus on training and identify program's that get workers into the primary labour market.

Other recommendations

- Tighten the conditions for public work schemes by efficient implementation of a profiling system, which redirects the unemployed to specific programmes according to their needs.

- Improve the evaluation of the efficiency of existing training programmes to better match different categories of participants to specific training programmes. Make individual action plans for unemployed mandatory and offer programmes with a mix of training, counselling and mentoring measures.

Improve educational outcomes to meet labour market needs

Key recommendation

- Assess recent reforms and continue integrating the vocational training programmes into secondary vocational schools. Increase funding and expand means-tested support for disadvantaged students. Provide incentives to tertiary institutions to better respond to labour market needs.

Other recommendations

- Develop quality assurance for apprenticeship places and ensures sufficient time for instruction relative to the productivity work.

- Continue to strengthen career counselling in order to improve responsiveness of tertiary education to labour market needs. Improve teacher's working conditions by further increasing their wages and reducing unnecessary administrative burdens.

- Make ICT training take up a more horizontal form of a knowledge application in all subjects through the curriculum.

- Postpone tracking and extend the period of compulsory grammar school to enhance general skills. 


\section{BIBLIOGRAPHY}

András G., R. Gál and G. Kézdi (2009) "The effects of child related benefits and pensions on fertility by birth order: A test on Hungarian data", Population Studies, 63:3, 215-231

DOI: $10.1080 / 00324720903215293$

Bassanini, A., A. Booth, G. Brunello, M. De Paola and E. Leuven (2005) "Workplace Training in Europe", IZA Discussion Papers, No. 1640, Institute for the Study of Labour.

BI (2010) "Evaluation of the Equal opportunity and integration project SROP 331" Budapest Institute.

Biró, P. (2012), "University admission practices - Hungary" www.matching-in-practice.eu

Blaskó, Zs. (2011) 'Három évig a gyermek mellett - de nem minden áron. Közvélemény a kisgyermekes anyák munkába állásáról' ['Stay at home for three years - but not at all costs. Social values on maternal employment in Hungary'], Demográfia, 2011/1: 23-45.

Bodnar, K. and L. Szabo (2014) "The Effect of Emigration on the Hungarian Labour Market" MNB Occasional Papers, Magyar Nemzeti Bank

Braconier, H., G. Nicoletti and B. Westmore (2014), "Policy challenges for the next 50 years", OECD Economic Policy Papers, No. 9, OECD Publishing, Paris, http://dx.doi.org/10.1787/5jz18gs5fckf-en

Buber-Ennser I., R. Panova (2014) "Attitudes towards Parental Employment across Europe, in Australia and in Japan" Vienna Institute of Demography.

Card D., J. Kluve and J. Weber (2015) "What Works? A Meta Analysis of Recent Active Labour Market Program Evaluations" NBER, Working Paper 21431 http://www.nber.org/papers/w21431

Chetty, R., J.Friedman and J. R. Rockoff (2014) "Measuring the Impacts of Teachers I: Evaluating Bias in Teacher Value-Added Estimates." American Economic Review, 104(9): 2593-2632. Working Paper 17699 http://www.nber.org/papers/w17699

Cools, S., J. H. Fiva, and L. J. Kirkebøen (2015) "Causal Effects of Paternity Leave on Children and Parents" The Scandinavian Journal of Economics, 117: 801-828.

doi: $10.1111 /$ sjoe. 12113

Cseres-Gergely, Z., A. Scharle and A. Foldessy (2015) "Evaluating the impact of a well-targeted wage subsidy using administrative data" Budapest working papers on the labour market BWP - 2015/3

Duell,N., et al. (2010), "Activation Policies in Switzerland", OECD Social, Employment and Migration Working Papers, No. 112, OECD Publishing, Paris.

DOI: http://dx.doi.org/10.1787/5km4hd7r28f6-en 
EC (2015) "Education and Training Monitor 2014 Hungary", European commission.

Eurobarometer (2010) "Employers' perception of graduate employability" Analytical report, Flash EB No 304, 2010

Eurofound (2015) "Third European Company Survey - Overview report: Workplace practices - Patterns, performance and well-being" Publications Office of the European Union, Luxembourg.

European Comission (2013) "Study on Policy Measures to improve the Attractiveness of the Teaching Profession in Europe - Final report" Volume 2.Luxembourg: Publications Office of the European Union

European commission, (2015a) "European Centre for the development of vocational training, Skill supply and demand up to 2025" Hungary country forecast.

European commission, (2015b) The 2015 Ageing Report, European Commission $\mathrm{http} / / / \mathrm{ec}$. europa.eu/economy_finance/publications/.

European commission, (2015 c) "Cost -benefit analysis of remedial intervention for the long-term unemployed", Brussels.

European commission, (2015d) "Education and training monitor 2015 Hungary", Brussels. http://ec.europa.eu/education/tools/docs/2014/monitor2014-hu_en.pdf

Fazekas K. and L. Neumann (2014) "The Hungarian Labour Market 2014, Centre for Economic and Regional Studies" Hungarian Academy of Sciences \& National Employment Non-profit Public Company Ltd, Budapest.

Fazekas K. and J. Varga (2015) "The Hungarian Labour market 2015" Centre for Economic and Regional Studies, Hungarian Academy of Sciences \& National Employment Non-profit Public Company Ltd, Budapest.

Feyrer, J, B. Sacerdote and A. Dora Stern (2008) "Will the Stork Return to Europe and Japan? Understanding Fertility within Developed Nations." Journal of Economic Perspectives, 22(3): 3-22.

Girasek, E., R. Csernus, K. Ragány and E. Eke (2013): "Migráció az egészségügyben" (Migration in Healthcare), Magyar Tudomany, 2013/3, Budapest: 292-298.

GVI (2012), "Diplomás pályakezdők a versenyszektorban - 2011" (Graduates in the private sector, 2011), Institute for Economic and Enterprise Research, Hungarian Chamber of Commerce and Industry.

Hajdu T., Z. Hermann, D.Horn, G. Kertesi, G. Kezdi, J. Kollo and J. Varga (2015) "Az érettségi védelmében" BUDAPESTI MUNKAGAZDASÁGTANI FÜZETEK BWP - 2015/1 C (2014)

Handel, M. (2012), "Trends in Job Skill Demands in OECD Countries”, OECD Social, Employment and Migration Working Papers, No. 143, OECD Publishing. http://dx.doi.org/10.1787/5k8zk8pcq6td-en

Herman, Z. (2013) "Are you on the right track? The effect of educational tracks on student achievement in upper-secondary education in Hungary", Working paper in the Labour market, Budapest. 
Herman Z. and D. Horn (2011) "How are inequality opportunity and mean student performance related? A quantile regression approaching using PISA data", Regional and Sectoral Economic Studies Vol. 11-3 (2011)

Herrmann, P., V. Bobkov and J. Csoba (2014) "Labour Market and Precarity of Employment: Theoretical Reflections and Empirical Data from Hungary and Russia" Wiener Verlag fuer Sozialforschung

Horn, D. (2013) "School-based Vocational or Workplace-based Apprenticeship Training? Evidence on the School-to-Work Transition of Hungarian Apprentices" European University Institute

Katay, G. and B. Nobilis (2009) "Driving forces behind changes in the aggregate labour force participation in Hungary" MNB Working Papers, No. 2009/5

Keller, J. and G. Mártonfi (2009) "Inequalities and special needs in education, in Education in Hungary" Hungarian Institute for Educational Research and Development, Budapest.

Keresztes, R. (2014) "Financing tertiary education: international and Hungarian examples of tuition fees" European Scientific Journal, edition vol.10, No.28, October.

Kollö. J. (2006) "Workplace literacy requirements and unskilled employment in east-central and western countries" Budapest working papers on the labour market institute of economics, Hungarian academy of sciences department of human resources, Corvinus university of Budapest, bwp-2006/7.

Martonfi, G. (2014) "Early leaving from vocational education and training Hungary", Observatory Centre for Educational Development, Corvinus University of Budapest.

MKIK (2014) "A szakképzett pályakezdők munkaerő-piaci helyzete és elhelyezkedési esélyei" Institute for Economic and Enterprise Research, Hungarian Chamber of Commerce and Industry.

Nyuisti, S. and Z. Veroszta (2013) "Hungarian graduate career tracking 2013" Education Public sector Non-profit LLC.

OECD. (2005a), Promoting Adult Learning, Education and Training Policy, OECD Publishing, Paris. DOI: http://dx.doi.org/10.1787/9789264010932-en

OECD (2005b) Teachers Matter, Attracting, developing and retaining and retaining effective children, http://www.oecd.org/edu/school/34990905.pdf

OECD. (2007), Babies and Bosses - Reconciling Work and Family Life: A Synthesis of Findings for OECD Countries, OECD Publishing, Paris. DOI: http://dx.doi.org/10.1787/9789264032477-en

OECD. (2008), International Migration Outlook 2008, OECD Publishing, Paris.

DOI: http://dx.doi.org/10.1787/migr_outlook-2008-en

OECD (2010), Learning for Jobs, OECD Reviews of Vocational Education and Training, OECD Publishing, Paris.

DOI: http://dx.doi.org/10.1787/9789264087460-en

OECD (2011a), Doing Better for Families, OECD Publishing, Paris.

DOI: http://dx.doi.org/10.1787/9789264098732-en 
OECD (2011b), Taxation and Employment, OECD Tax Policy Studies, No. 21, OECD Publishing, Paris. DOI: http://dx.doi.org/10.1787/9789264120808-en

OECD (2012a), OECD Economic Surveys: Hungary 2012, OECD Publishing. http://dx.doi.org/10.1787/9789264127272-en

OECD (2012b), "Does Performance-Based Pay Improve Teaching?", PISA in Focus, No. 16, OECD Publishing,Paris.

DOI: http://dx.doi.org/10.1787/5k98q27r2stb-en

OECD (2012c), "How Are Countries Around the World Supporting Students in Higher Education?", Education Indicators in Focus, No. 2, OECD Publishing, Paris.

DOI: http://dx.doi.org/10.1787/5k9fd0kd59f4-en

OECD (2013a), "PISA 2012 Results: Excellence through Equity: Giving Every Student the Change to Succeed, Vol. II, preliminary version" OECD Publishing, Paris, doi:http://dx.doi.org/10.1787/9789264201132-en.

OECD (2013b), "How Do Early Childhood Education and Care (ECEC) Policies, Systems and Quality Vary Across OECD Countries?", Education Indicators in Focus, No. 11, OECD Publishing, Paris. DOI: http://dx.doi.org/10.1787/5k49czkz4bq2-en

OECD (2013c), Education at a Glance 2013: OECD Indicators, OECD Publishing. http://dx.doi.org/10.1787/eag-2013-en

OECD (2014a), OECD Economic Surveys: Hungary 2014, OECD Publishing. http://dx.doi.org/10.1787/eco surveys-hun-2014-en

OECD (2014b), International Migration Outlook 2014, OECD Publishing. http://dx.doi.org/10.1787/migr_outlook-2014-en

OECD (2014c), PISA 2012 Results: Creative Problem Solving: Students' Skills in Tackling Real-Life Problems (Volume V), PISA, OECD Publishing. http://dx.doi.org/10.1787/9789264208070-en

OECD. (2015a), The Future of Productivity, OECD Publishing, Paris. DOI: http://dx.doi.org/10.1787/9789264248533-en

OECD (2015b), Government at a Glance: How Hungary Compares, OECD Publishing, Paris. http://dx.doi.org/10.1787/9789264233720-en

OECD (2016), OECD Economic Surveys: Hungary 2016, OECD Publishing, Paris. DOI: http://dx.doi.org/10.1787/eco_surveys-hun-2016-en

Public Education Development Strategy (2014), Budapest

Rodríguez-Planas N. and D. Fernández Kranz (2013) "Can Parents' Right to Work Part-Time Hurt Childbearing-Aged Women? A Natural Experiment with Administrative Data" IZA Discussion Paper No. 7509, 2013 
Seemig, A. (2014), "Managing Migration in South East Europe transznacionális együttmüködési project" Helyzetkép a magyarországi elvándorlásról" című sajtótájékoztatójának sajtóanyaga, Központi Statisztikai Hivatal, 2014

Scharle, A. (2015) "Public works programmes in Slovakia, The Hungarian Labour market 2015" Centre for Economic and Regional Studies, Hungarian Academy of Sciences.

Talent Shortage survey (2015), Manpower group,

$\mathrm{http} / / / \mathrm{www} . \mathrm{manpowergroup.com/wps/wcm/connect/db23c560-08b6-485f-9bf6-}$ f5f38a43c76a/2015_Talent_Shortage_Survey_US-lo_res.pdf?MOD=AJPERES

Tremblay, K., D. Lalancette and D. Roseveare (2012) "Assessment of Higher Education Learning Outcomes Feasibility Study Report" Design and Implementation.

UK (2015) "Department for Education, Government response to workload challenge" https://www.gov.uk/government/publications/workload-challenge-for-schools-government-response. Df

Varga, J. (2014) “Teacher salaries, teachers' selection and turnover”, The Hungarian Labour Market.

Varga, J. (2013), "Labour Market Success of Hungarian Higher Education Graduates in 2011", Hungarian Graduates 2011, Education Public Services, Ministry for Human Resources.

World bank (2016), "R. Gatti, S. Karacsony, K. Anan, C. Ferré, C. de Paz Nieves: Being Fair, Faring Better Promoting Equality of Opportunity for Marginalized Roma", World bank. 